Georgia State University

ScholarWorks @ Georgia State University

$4-2013$

\title{
Reforming Subsidies for Fossil Fuel Consumption: Killing Several Birds with One Stone
}

Charles E. McLure Jr.

Stanford University

Follow this and additional works at: https://scholarworks.gsu.edu/icepp

Part of the Economics Commons

\section{Recommended Citation}

McLure, Charles E. Jr., "Reforming Subsidies for Fossil Fuel Consumption: Killing Several Birds with One Stone" (2013). ICEPP Working Papers. 52.

https://scholarworks.gsu.edu/icepp/52

This Working Paper is brought to you for free and open access by the International Center for Public Policy at ScholarWorks @ Georgia State University. It has been accepted for inclusion in ICEPP Working Papers by an authorized administrator of ScholarWorks @ Georgia State University. For more information, please contact scholarworks@gsu.edu. 
INTERNATIONAL CENTER FOR PUBLIC POLICY
International Center for Public Policy Working Paper 13-12

April 2013

Reforming Subsidies for Fossil Fuel

Consumption: Killing Several Birds with One Stone

Charles E. McLure, Jr.

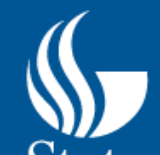

GeorgaState University
ANDREWYOUNG SCHOOL 



\author{
International Center for Public Policy \\ Working Paper 13-12
}

\title{
Reforming Subsidies for Fossil Fuel Consumption: Killing Several Birds with One Stone
}

Charles E. McLure, Jr.

April 2013

International Center for Public Policy

Andrew Young School of Policy Studies

Georgia State University

Atlanta, Georgia 30303

United States of America

Phone: (404) 651-1144

Fax: (404) 651-4449

Email: hseraphin@gsu.edu

Internet: http://aysps.gsu.edu/isp/index.html

Copyright 2006, the Andrew Young School of Policy Studies, Georgia State University. No part of the material protected by this copyright notice may be reproduced or utilized in any form or by any means without prior written permission from the copyright owner. 


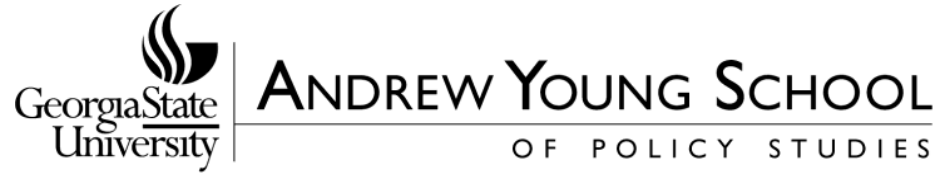

\section{International Center for Public Policy Andrew Young School of Policy Studies}

The Andrew Young School of Policy Studies was established at Georgia State University with the objective of promoting excellence in the design, implementation, and evaluation of public policy. In addition to two academic departments (economics and public administration), the Andrew Young School houses seven leading research centers and policy programs, including the International Center for Public Policy.

The mission of the International Center for Public Policy is to provide academic and professional training, applied research, and technical assistance in support of sound public policy and sustainable economic growth in developing and transitional economies.

The International Center for Public Policy at the Andrew Young School of Policy Studies is recognized worldwide for its efforts in support of economic and public policy reforms through technical assistance and training around the world. This reputation has been built serving a diverse client base, including the World Bank, the U.S. Agency for International Development (USAID), the United Nations Development Programme (UNDP), finance ministries, government organizations, legislative bodies and private sector institutions.

The success of the International Center for Public Policy reflects the breadth and depth of the in-house technical expertise that the International Center for Public Policy can draw upon. The Andrew Young School's faculty are leading experts in economics and public policy and have authored books, published in major academic and technical journals, and have extensive experience in designing and implementing technical assistance and training programs. Andrew Young School faculty have been active in policy reform in over 40 countries around the world. Our technical assistance strategy is not to merely provide technical prescriptions for policy reform, but to engage in a collaborative effort with the host government and donor agency to identify and analyze the issues at hand, arrive at policy solutions and implement reforms.

The International Center for Public Policy specializes in four broad policy areas:

- Fiscal policy, including tax reforms, public expenditure reviews, tax administration reform

- Fiscal decentralization, including fiscal decentralization reforms, design of intergovernmental transfer systems, urban government finance

- Budgeting and fiscal management, including local government budgeting, performancebased budgeting, capital budgeting, multi-year budgeting

- Economic analysis and revenue forecasting, including micro-simulation, time series forecasting,

For more information about our technical assistance activities and training programs, please visit our website at http://aysps.gsu.edu/isp/index.html or contact us by email at hseraphin@gsu.edu. 


\title{
Reforming Subsidies for Fossil Fuel Consumption: Killing Several Birds with One Stone
}

\author{
Charles E. McLure, Jr. ${ }^{1}$
}

Hoover Institution

Stanford University

\footnotetext{
${ }^{1}$ The author thanks Richard Bird for useful comments on a preliminary draft of this paper, but assumes sole responsibility for the views expressed here and for any errors.
} 
"As most fuel subsidies accrue to higher income households, it should be possible to eliminate or substantially reduce subsidies, use some of the budgetary savings to finance better targeted-programs to compensate the poorest households, and still have funds left over." - Baig, Mati, Coady, and Ntamatungiro (2007), p. 14

\section{Introduction}

Many developing countries subsidize uneconomic activities. Besides distorting the allocation of resources, subsidies squander scarce public funds, aggravating the problem of revenue mobilization. Governments of developing countries could pick low-hanging revenue fruit by eliminating uneconomic subsidies.

Subsidies for the consumption of fossil fuel are especially wasteful. In addition to the negative impacts on resource allocation and public finances mentioned above, they fritter away foreign exchange, complicate demand management, aggravate energy insecurity, and encourage traffic congestion and air pollution. In addition to these undesirable effects, which, with the exception of some forms of air pollution, affect primarily the country subsidizing fuel consumption, these subsidies encourage the emission of $\mathrm{CO} 2$, the most plentiful greenhouse gas (GHG) thought to be responsible for climate change. Because climate change is a global problem, Annex 1 signatories of the Kyoto Protocol, (essentially advanced countries and some countries in transition from socialism) pledged:

Progressive reduction or phasing out of market imperfections, fiscal incentives, tax and duty exemptions and subsidies in all greenhouse gas emitting sectors that run counter to the objective of the Convention and application of market instruments; ${ }^{2}$

In September 2009, leaders of the Group of Twenty (G-20) largest industrialized and developing economies, in a bid to advance their energy security and climate change agendas, made a nonbinding commitment "to rationalize and phase out over the medium term inefficient fossil-fuel subsidies that encourage wasteful consumption." 3 . In November 2009, leaders of the Asia-Pacific Economic Cooperation, which includes some developing countries, as well as advanced countries and countries in transition, made a similar commitment. ${ }^{4}$ Recognizing the costs described above, many developing countries have made unilateral commitments to reduce subsidies. $^{5}$

This paper examines subsidies for the consumption of fossil fuels provided by developing countries and oil-exporting countries. (In what follows all unqualified references to fuel

\footnotetext{
${ }^{2}$ Kyoto Protocol, (Article 2(a)(v).

${ }^{3}$ G-20 Leaders (2009)

${ }^{4}$ APEC Leaders (2009).

${ }^{5}$ Issues of World Energy Outlook for various years describe some of these commitments, progress in fulfilling them, and political impediments to doing so.
} 
subsidies are to subsidies for the consumption of fossil fuels, including electricity that is generated by combusting fossil fuel. Thus neither production subsidies nor subsidies for other types of energy, such as hydro, solar, wind, and nuclear, are considered. ${ }^{6}$ In this context, "consumption" does not mean only household consumption; it includes consumption by business and governments.)

The next section describes the negative effects of fuel subsidies mentioned above in greater detail. Although emphasis in this paper, as in most of the literature and in policy discussions, is on eliminating fuel subsidies, it should be emphasized that reforming fuel subsidies does not necessarily mean eliminating them quickly. There may be cases in which temporary, limited, and well-targeted fuel subsidies are appropriate. No effort has been made to identify these cases, which would require case-by-case analysis of the situation in particular countries.

Progress has been made in recent years in reducing or eliminating subsidies to the consumption of fossil fuels, but much remains to be done. ${ }^{7}$ Section III discusses briefly how fuel subsidies are defined, describes the price-gap methodology commonly used in cross-country comparisons of consumption subsidies, indicates some shortcomings in that methodology, and notes that the level of subsidies is quite sensitive to international fuel prices, moving in concert with them. Section IV presents estimates of fossil fuel consumption subsidies for the 37 countries on which the International Energy Agency has complete data. The section then briefly describes some of the implications of eliminating subsidies, focusing on potential budget impacts in countries that, as a fraction of GDP, run significant budget deficits and spend significant amounts on fuel subsidies.

Fuel consumption subsidies are often defended as alleviating poverty, and some subsidies may further this objective. But, because fuel subsidies are often poorly targeted, the distributional impact of many subsidies is regressive, or at best proportionate to income. Regressivity is especially likely in most of the countries of Sub-Saharan Africa and some of those in Asia, where only a small minority of the population - fewer than 10 percent in many countries - uses modern fuels and may not even have access to them. It is often the middle class who benefit the most from fuel subsidies - and who defend them most adamantly. ${ }^{8}$ Section V discusses the distributional impact of eliminating subsidies, which varies from country to country, as well as by the type of fuel subsidized.

Although fuel subsidies are costly and are not well-targeted to relieve poverty, eliminating subsidies may impose onerous burdens on the poor. It may thus be necessary, for

\footnotetext{
${ }^{6}$ On subsidies to non-renewable energy, see IEA (2011a), pp. 527-40 and IEA (2012a), pp. 233-36. Fuel subsidies are commonly characterized as being related to production or to consumption. Production subsidies are important in both advanced and developing countries. Most fuel consumption subsidies occur in non-OECD countries. IEA (2011a), p. 509.

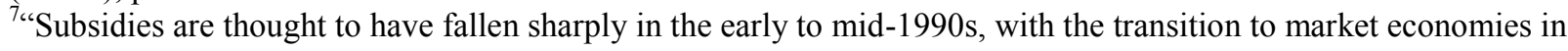
the former communist bloc countries, but may have risen in recent years as many non-OECD countries have sought to prevent higher international energy prices from feeding into final prices for social reasons." UNEP (2008), p. 10. In addition to fostering energy-inefficient manufacturing, the Soviet system failed to price properly the electricity and heat delivered to commercial and residential customers. Petri, Taube, and Tsyinski (2003). See also World Energy Outlook for various years.

${ }^{8}$ If, as Dr. Samuel Johnson famously proclaimed in 1775 , "Patriotism is the last refuge of the scoundrel," perhaps protecting the poor is the scoundrel's next-to-last refuge.
} 
humanitarian as well as political reasons, to accompany subsidy reform with measures to alleviate the burden on the poor. Section VI examines measures that can be used to protect the poor when fuel consumption subsidies are reformed. Lack of space and expertise precludes discussion of the important issues involved in implementing fuel subsidy reform, including means of increasing support for reform by addressing distributional concerns. ${ }^{9}$

The use of biomass (firewood, charcoal, straw, agricultural residue, or dung) or coal for cooking and heating has several serious disadvantages: inter alia, emissions of GHGs are greater than with fossil fuels other than coal, dangerous indoor air pollution leads to impaired health, especially for women and small children, use of biomass often requires devotion of many hours to gathering fuel, again commonly by women and children, and, where dung is used for fuel, it causes deterioration of soil fertility. In recent years substantial attention has been devoted to assuring access to clean energy for all. ${ }^{10}$ An alternative argument for subsidizing the use of fossil fuels, albeit one that probably does not explain the prevalence of subsidies, is thus to induce poor households to shift from biomass and coal (solid or "traditional fuels") to modern (non-solid) fuels (kerosene, gas, and electricity). Section VII discusses the use of fuel subsidies to encourage consumers to switch from traditional fuels to modern fuels.

A short concluding section draws some tentative conclusions, based on the analysis presented earlier. There is clearly a strong case for reforming subsidies to the consumption of fossil fuels, as reform would improve environmental, economic, and budgetary, performance in countries now providing fuel subsidies. Care must be taken, however, to avoid or offset adverse effects on the real income of the poor.

A caveat is in order at this point. The author is not expert in the topics examined here. Moreover, the appropriateness of these conclusions for any given country should be subject to further much more detailed examination, as it is unlikely that "one size fits all." Rather, as the UNEP has warned, "The right policy approach for each country must take account of local market conditions, the structure of the energy sector, patterns of energy use, institutional characteristics, and changing circumstances." 11 See also the third caveat at the end of Section III.

\section{Disadvantages of Subsidies for Fossil Fuel Consumption ${ }^{12}$}

In the absence of external costs and benefits, prices paid by consumers reflect social benefits, and marginal costs of imports and local production represent social costs, as does the

\footnotetext{
${ }^{9}$ See, however, Gupta et al. (2000), UNEP (2004), pp. 147-54, UNEP (2008), pp. 20-29, Victor (2009), Laan (2010), IEA, OPEC, OECD, and World Bank (2010), pp. 33-37, IEA, OECD, and World Bank (2010), pp. 27-36, IEA (2011), pp. 522-27, and APEC (2012), pp. 54-68.

${ }^{10}$ The IEA (2011), p. 471, notes that the UN has declared 2012 to be the "International Year of Sustainable Energy for All." IEA (2012a), chapter 18 is devoted to "Measuring Progress towards Energy for All."

${ }^{11}$ UNEP (2008), p. 7.

${ }^{12}$ Among the many places these disadvantages are discussed are Gupta, Clements, Fletcher, and Inchauste (2003), UNEP (2004), pp. 147-54, OECD (2009), pp. 101-109, IEA, OPEC, OECD, and World Bank (2010), and APEC (2012), all of which provide extensive bibliographies. IEA, OECD, and World Bank (2010), pp. 27-36, provides an excellent synthesis. Reducing the problems associated with fuel subsidies is sometimes said to be essential to achievement of the millennium development goals and the three pillars of sustainable development: economy, social welfare, and environment. See, for example, UNEP (2008), p. 5, IEA, OPEC, OECD, and World Bank (2010), and UN-Energy (2005), p. 6-7.
} 
price that can be obtained for exports. (In the case of exports the cost is an opportunity cost what could be derived from exportation.) If, in addition, there are no non-competitive influences, prices reflect social coasts.

\section{A. The Economic and Environmental Costs of Fuel Subsidies}

If these assumptions hold, consumption subsidies drive a wedge between the costs of products and their prices, and thus between the social cost and benefits of subsidized products. At the margin, subsidized consumption is worth less than it costs. (This is perhaps most easily seen when scarce foreign exchange is being used to import subsidized petroleum products or when excessive amounts of subsidized petroleum products are being consumed domestically, rather than being exported to earn foreign exchange. In either case foreign exchange could be used to buy imported goods and services that are valued more highly than the subsidized petroleum products.) The result of excessive consumption of subsidized fuel is a sacrifice of potential welfare, often called deadweight loss. Even though the extreme assumptions underlying this model of welfare maximization do not accurately describe reality, it is generally thought that, with some important exceptions, free market prices approximate values fairly closely. This is the reasoning that underlies both the case for subsidy reform and the price-gap methodology described in the next section.

In the case of subsidies for fossil fuel consumption, the assumption that there are no external costs is not valid. The combustion of fossil fuels releases carbon dioxide and other greenhouse gases, gaseous air pollutants (notably nitrous oxides and sulphur dioxide), and particulates that cause respiratory disease. This means that the optimal price for fossil fuels would lie above what it costs to produce or import them what could be gained from exporting them. ${ }^{13}$ Subsiding the consumption of fossil fuels thus creates a two-fold distortion of resource allocation: by encouraging both overconsumption (even if there were no environmental impact) and environmental damage. Subsidies for other kinds of consumption, although uneconomic, generally lack the second form of distortion.

It is common for fuel that is subsidized to be in short supply; after all, because of the subsidy, it costs less to buy the fuel than it is does to produce or import it. ${ }^{14}$ Aggravating shortages, kerosene can be substituted for unsubsidized diesel fuel for use in motor vehicles and stationary engines, ${ }^{15}$ and subsidized fuel may be smuggled to other countries, where it can be sold for more than its subsidized price. When shortages occur, it is likely to be the poorest members of society who must do without fuel, because of "petty corruption and favouritism," even if fuel is rationed. ${ }^{16}$ Moreover, implementing fuel rationing and preventing diversion of fuel

\footnotetext{
${ }^{13}$ It can be argued that, from the perspective of any one country, the price of fuel should reflect only social costs occurring in that country - that it should not reflect the world-wide damage caused by the release of greenhouse gases. In other words, the price that is optimal for a single country may not be optimal from a worldwide point of view. Measurement of price-gaps generally does not take account of external costs. If it does, it generally does not distinguish between external costs that are experienced within the country and those that are experienced outside. ${ }^{14}$ UNEP, (2008), p. 15, notes that state-owned suppliers of LPG in India were forced to ration supply to limit their losses.

${ }^{15}$ Baig, Mati, Coady, and Ntamatungiro (2007), pp. 16, note 7, cite a World Bank study that estimates that half of the subsidized kerosene sold in India is used to power vehicles.

${ }^{16}$ UNEP (2008), p. 14.
} 
to unsubsidized uses and smuggling is a complex activity that absorbs administrative resources that are commonly scarce in developing countries and could be put to better uses.

Fuel subsidies do not merely result in overconsumption, deadweight loss, environmental damage, and shortages, which can be characterized as static effects. They can also have negative dynamic effects. By suppressing opportunities for profit and restraining cash flow of state oil companies, subsidies can deter investment in the energy sector. The poor, ostensibly the target population for subsidies, are likely to bear the brunt of the resulting energy shortages, as occurred in India. ${ }^{17}$

Fuel subsidies also discourage investment in energy-efficient technologies by businesses (including those engaged in agriculture), households (for example, in the choice of automobiles, building design, and appliances), and governments and, by cheapening the cost of transportation, encourage energy-inefficient urban development. Since many of these investments have long lives, countries that subsidize fossil fuel can be locked in to energy-inefficient investments for long periods. The result is excessive emissions of GHGs and pollution, as well as unnecessary economic costs.

The deadweight loss and external costs associated with fuel subsidies may actually be fairly small in the short run, when fuel consumption is relatively unresponsive to changes in price (that is, fuel demand is price-inelastic). In that case the primary cost is budgetary (discussed below). But costs increase over time, as demand becomes more responsive to price. Moreover, both smuggling to markets where fuel prices are higher and substitution of subsidized fuel for unsubsidized fuel are likely to be quite price-elastic.

A shortage of foreign exchange is a chronic problem for many developing countries. Subsidizing the consumption of fossil fuels aggravates such shortages, regardless of whether the country is net importer or a net exporter of fuel, by either encouraging imports of fuel or discouraging fuel exports, other than cross-border smuggling. Even if fuel exporting countries do not feel the pinch immediately, they may do so in the long run, as excess consumption hastens depletion of fuel reserves and thus the decline of exports and eventual reliance on imports..

One often overlooked implication of the inefficient use of energy is fuel insecurity. It requires more fuel - and thus more foreign exchange, in the case of fuel importers - to power an energy-inefficient economy. Even countries that export fuel, or could, if domestic prices reflected opportunity costs, may experience energy insecurity because of their addiction to consumption of subsidized fuel. When energy is unavailable, or is available only at a prohibitive cost, economic activity grinds to a crawl, homes and workplaces grow cold and dark, transportation, for both business and pleasure, is curtailed, and national security suffers. This effect is more pronounced, the more energy-inefficient is a country's consumption and production. Given that fuel subsidies encourage profligate use of energy, energy security would be enhanced by their elimination. ${ }^{18}$

\footnotetext{
${ }^{17}$ See UNEP (2008), p, 29, regarding financial impediments to rural electrification.

${ }^{18}$ In principle, global energy security is undermined by the presence of fuel subsidies in any country. The oligopolistic production ceilings set by OPEC offset (some, all, or more than all of) the global effects of fuel subsidies.
} 


\section{B. The Budgetary Cost of Fuel Subsidies}

Many developing countries have difficulty mobilizing adequate public revenues. As a result, they under-provide public services or rely on taxes that distort resource allocation or on excessive borrowing or inflationary money creation. As documented in Section IV, fuel subsidies constitute a significant drain on government revenues in some developing countries, countries in transition, and oil-producing countries. ${ }^{19}$ These budgetary costs increase when international fuel prices rise, unless domestic fuel prices are adjusted to reflect those increases. Smuggling and the use of subsidized fuel for unintended purposes aggravates the budgetary cost of subsidies.

Fuel subsidies may be either explicit, requiring budgetary expenditures, or implicit. Baig, Mati, Coady, and Ntamatungiro (2007), p. 10, observe, "Explicit subsidies mainly reflect compensation to the national energy company for the increased difference between the wholesale domestic price and the world price of fuels." By comparison (p. 9), "The initial cost of implicit subsidies is typically assumed by the national oil company without explicit compensation through the budget.." ${ }^{20}$ Only explicit subsidies are likely to reflected as current expenditures in governments budgets. Implicit subsidies may eventually be reflected in revenues not realized, for example, as taxes or dividends not received from state-owned oil companies. ${ }^{21}$ In some cases subsidies may not entail a fiscal cost, as when export bans increase supply to the domestic market and drive down end-use prices of fuels.

Eliminating fuel subsidies may offer an attractive source of revenue. Besides avoiding distortions in fuel prices, eliminating fuel shortages, preventing illicit use and smuggling of subsidized fuel, alleviating foreign exchange problems, enhancing energy security, and curtailing pollution and the emission of greenhouse gases, such a policy would allow, in some combination, the expansion of public services, the reduction of taxes that distort the allocation of other goods and services (including those of labor and capital), and the avoidance of excessive and perhaps unsustainable borrowing and inflationary money creation. The magnitude of this "multiple dividend" 22 will depend on how much of the revenues saved by not subsidizing fuel consumption must be diverted to protect the real income of the poor, the topic of Section VI. ${ }^{23}$

\footnotetext{
${ }^{19}$ For example, Indonesia and Yemen spend more on oil subsidies than on health and education combined. UNEP (2008), p. 13.

${ }^{20}$ Baig, Mati, Coady, and Ntamatungiro (2007), p. 10, present figures for explicit and implicit fuel subsidies, as a percentage of GDP, for 2003 (actual), 2005 (estimated), and 2006 (projected), for 16 countries.

${ }^{21}$ Espinasa (2003) points out that the effect on the government take (tax receipts and dividends) will be lower, the lower is the income tax rate and the lower the share of after-tax profits of state oil companies paid in dividends.

${ }^{22}$ Using a Pigouvian tax to cause prices to reflect the social cost of environmental damage related to pollution and using revenues from the tax to reduce distortionary taxes entails a double dividend. The first dividend is the reduction in environmental damage caused by the tax and the second is the improvement in resource allocation resulting from the use of revenues from the tax to replace those from distortionary taxes. See Goulder (1995). As noted in the text, eliminating fuel subsidies involves several other dividends, in addition to dividends analogous to these two. In either case the second dividend may be the expansion of valuable public services or the avoidance of debt or money creation, rather than the reduction of distortionary taxes.

${ }^{23}$ Referring to subsidies that "harm the environment, bring few social benefits and carry large economic costs," UNEP (2008), p. 22, notes that "subsidy removal, in this case, would be a triple-win policy reform." Similarly, IEA, OECD, and World Bank (2010), p. 3, says, "Phasing-out fossil-fuel subsidies represents a triple-win solution. It would enhance energy security, reduce emissions of greenhouse gases and bring immediate economic gains." In both of these descriptions, budgetary savings and positive foreign exchange effects are included in economic gains. Thus, referring to subsidies, IEA, OECD, and World Bank (2010), p. 3, says, "they are creating market distortions,
} 


\section{Caveats}

There are three important caveats - two specific and one general - to the case for eliminating all fossil fuel subsidies - and perhaps a case for subsidizing consumption of fossil fuels other than coal under certain circumstances. First, despite the negative effects of fossil fuel subsidies described thus far and the undesirable distributional consequences of subsidies to be described in Section V, eliminating all such subsidies could have an onerous effect on the poor in some countries. It may thus be appropriate to retain some fuel subsidies. But subsidies should be much more limited in scope and much better targeted, and thus less costly, in terms of economic distortions, environmental degradation, and negative impacts on public budgets, balance of payments, energy security, and the distribution of income. Cash payments or the expansion of key public services that benefit the poor disproportionately are often better options. See also Section VI.

Second, in some of the poorest countries, biomass (wood, charcoal, straw, agricultural residue, and dung) or coal are the primary fuels used in cooking and household heating. The IEA estimates that in 2010 almost 2.6 billion persons worldwide, $38 \%$ of the global population, relied on biomass, ${ }^{24}$ if users of coal are added, the figure is about 3 billion. ${ }^{25}$ Ninety-five percent of these using biomass are found in Sub-Saharan Africa and the developing countries of Asia. More than $90 \%$ of the population of several African countries relies on biomass, and this rate is $68 \%$ for the continent considered as a whole, even though it is only $1 \%$ in North Africa. ${ }^{26}$ Section VII considers whether fuel subsidies should be used to induce switching from these traditional fuels to modern fossil fuels.

These two caveats lead to a third and more general truth, that there is no "one size fits all" when it comes to the reform of fossil fuel subsidies. The UNEP has captured both the general case for market allocation of resources, which implies the elimination of fuel subsidies, and the possibility that subsidies may be needed under some circumstances, in stating:

The right policy approach for each country must take account of local market conditions, the structure of the energy sector, patterns of energy use, institutional characteristics, and changing circumstances. However, there is a broad consensus on the need for an approach that promotes efficient, competitive energy markets as the foundation upon which government policies should be superimposed. Getting market signals right so that prices better reflect the true costs of producing

\footnotetext{
imposing an unsupportable fiscal burden on government budgets and are weakening trade balances." It is clear that there are more than three "wins."

${ }^{24}$ IEA (2012a), p. 532, Table 18.1. The countries with the largest reliance on biofuels are India, with 772 million, China (387 million), Bangladesh (149 million), Indonesia (128 million), and Pakistan (111 million). In Bangladesh $91 \%$ of the population relies on biomass; that percentage is lower in the other Asian countries mentioned here.

${ }^{25}$ Roughly 400 million people, most of them in China, rely on coal. IEA (2012a), p. 532, note 5.

${ }^{26}$ IEA (2012a), p. 532, Table 18.1. For a more comprehensive survey of biomass use, see UNDP and WHO (2009) and Ekouevi and Tuntivate (2011), pp. 2-5.
} 
and consuming energy - i.e. taking account of the environmental and social consequences - should be a key guiding principle in all cases. ${ }^{27}$

\begin{abstract}
However, there may be instances in which subsidising modern energy use might bring some environmental benefits. For example, encouraging the use of oil products can curb deforestation in developing countries as poor rural and periurban households stop using firewood. This can in turn boost carbon sinks and potentially offset the emissions from fuel combustion. Additionally, subsidies for oil products and electricity in poor countries can reduce indoor pollution by encouraging inhabitants to switch away from traditional energies like wood, straw, crop residues and dung. ${ }^{28}$
\end{abstract}

While there may be a presumption that fuel subsidies should be eliminated, this cannot be known without a careful analysis of the details of the subsidies provided in a particular country. Since lack of both time and expertise precludes such analyses, no attempt is made, with a few exceptions, to draw firm conclusions regarding proper policy for a particular country from the results presented below.

\title{
III. Methodological Issues in Estimating Fossil Fuel Consumption Subsidies
}

Following a very brief and general definition of fuel subsidies, this section describes the price-gap methodology that is commonly used to estimate fuel subsidies and compare them across countries and indicates some of the problems inherent in the use of that methodology. The final subsection notes that estimates of the amounts and rates of subsidization can be quite volatile, varying with the international price of fuels.

\section{A General Definition of Fuel Subsidies}

Before fuel subsidies can be quantified, it must be known what they are. The OECD (1998) has defined a subsidy as "any measure that keeps prices for consumers below market levels, or for producers above market levels or that reduces costs for consumers and producers." 29 (Emphasis added to highlight aspects relevant to the definition of consumption subsidies) Although this definition is quite general, it is adequate for present purposes. ${ }^{30}$ The

\footnotetext{
${ }^{27}$ UNEP (2008), p. 7.

${ }^{28}$ UNEP (2008), p. 15. It is now understood that using wood for heating and cooking does not ordinarily cause deforestation, since most of wood is gathered, not cut. Also, it appears that fuel subsidies may not be effective in inducing fuel switching. See Section VII.

${ }^{29}$ Similarly, the International Energy Agency (IEA) (2011, p. 509) has defined energy subsidies as "any government action that concerns primarily the energy sector that lowers the cost of energy production, raises the price received by energy producers or lowers the price paid by energy consumers."

${ }^{30}$ The US Energy Information Administration (1992, p. 2) is more expansive, describing an energy subsidy as "any government action designed to influence energy market outcomes, whether through financial incentives, regulation, research and development or public enterprises." GSI (2010) discusses alternative ways of defining fuel subsidies.
} 
price-gap methodology below, as well as the previous discussion of the disadvantages of fuel subsidies, is consistent with it. Subsidies for the consumption of fossil fuels occur primarily because governments fix prices for fuel, which is often sold by state-owned enterprises, below market prices.

\section{B. Two Ways to Estimate Fuel Subsidies}

Estimates of fossil fuel consumption subsidies for a given country can be built from the bottom up, by detailed analysis of subsidies. While such estimates are essential in informing subsidy reform in a particular country, including the design of policies to mitigate economic dislocation felt by vulnerable populations, they are time- and data-intensive, they are not available for many countries, and it is difficult to compare them across countries.

The most common way to estimate fuel subsidies involves the price-gap methodology. This approach simply calculates the difference between the average end-use prices paid by consumers of fossil fuels and the full cost of fuel, commonly called the reference price. Although estimates based on this methodology are less precise than bottom-up estimates, and for that reason generally cannot be used as the basis for designing fuel subsidy reform, they can more easily be produced for many countries, utilizing a common methodology, facilitating comparisons across countries. Moreover, they can be produced without the cooperation of governments that may not want to reveal the details of their subsidy programs or provide the data required for the bottom-up approach. But, as explained below, implementation of the price-gap methodology is not as simple as the description above may suggest, and there are many problems with it. The International Energy Agency (IEA) emphasizes that its estimates of consumption subsidies should be considered a lower bound on the economic cost of fuel subsidies. ${ }^{31}$

\section{The Price-gap Methodology}

The reference price is derived by adding the cost of internal transportation, insurance, distribution, and applicable value-added tax (VAT) to the cost of fuel, exclusive of those costs, which here will be called the "basic cost." 32 For imports of oil products, natural gas, and coal, the basic cost is the landed price of fuels, adjusted for differences in quality; for exports, it is the export price. (The calculation is somewhat more complicated in the case of exported fuel; it may

APEC (2012), pp. 13-14, is one of many publications providing more specific descriptions and examples of policies that subsidize the production or consumption of energy.

${ }^{31} \operatorname{IEA}(2011 \mathrm{a})$, p. 513.

${ }^{32}$ This term is not commonly used; it is employed here solely for expositional convenience. Coady et al. (2010), pp 4-6, distinguish "tax-exclusive" and "tax-inclusive" subsidies. The latter include "optimal taxes," in addition to marginal supply costs. Optimal taxes, which are not included in the reference prices on which the current discussion is based, include charges for environmental damage, and, in accord with the Ramsey rule for optimal commodity taxation, may be inversely related to the price elasticity of demand, in order to minimize distortion in consumption choices. The inelasticity of demand for fuel, at least in the short run, as well as the existence of important external costs, suggests that taxes on fossil fuel should be higher than those on other products. See Coady et al. (2010), p 5. Tax inclusive subsidies would therefore be larger than tax-exclusive subsidies. Moreover, whereas subsidies for fuel consumption calculated on a tax-exclusive basis occur almost exclusively in developing countries, subsidies calculated on a tax-inclusive basis would also occur in developed countries and would be quite large in the United States and China, the largest emitters of GHGs. 
be necessary to net out the cost of transportation to shipping terminals before adding in the cost of domestic transportation.) For non-traded fuel and electricity the basic cost is the long-run marginal cost of production. ${ }^{33}$ For countries that both produce and import fuel, the reference price is a weighted average. The reference price of electricity generated by combusting fossil fuel is based on the annual cost of production, which depends, inter alia, on the mix of fuels used in generation and the reference prices of fuels. ${ }^{34}$

It is important to emphasize that the cost of production is not relevant in calculating the subsidy in most fuel-exporting countries. As indicated earlier, the relevant cost is the opportunity cost of fuel - what it would bring in the export market. In low-cost countries this may be well above the cost of production, in which case basing calculations of subsidies on production costs would produce a substantial understatement. Confusion on this issue - and the fact that subsidies may be implicit - may help explain why fuel-exporting countries subsidize consumption of fossil fuels, often quite heavily. ${ }^{35}$ Whether or not such confusion exists, subsidized pricing of fuel may represent a way of sharing mineral wealth with the population, albeit a highly distortionary and undesirable way. ${ }^{36}$

\footnotetext{
${ }^{33}$ IEA (2011a), p. 512. Gupta, Clements, Fletcher, and Inchauste (2003), pp. 385-89 and Appendix, also provide an excellent description of this methodology. As noted below, Koplow (2009) points out deficiencies in the methodology.

${ }^{34}$ Underpricing of fuel may not result only from setting end-use prices below reference prices. Under-collection of bills, which may or may not reflect a conscious policy, and theft of energy (for example, through illegal electric connections and diversion of fuel from pipelines) may also contribute to the de facto underpricing of fuel. See IEA (2011a), p. 515. Under-collection and energy theft arguably should not be considered to be subsidies, even if they are reflected in price gaps, unless condoned as a matter of policy. It is unclear whether the IEA estimates of subsidies include the effects of under-collection and theft.

${ }^{35}$ In a 2010 report to the G-20, the OPEC Secretariat stated that "for countries that are well-endowed with energy ... the benchmark used should concern the cost of production rather than the international market price." See OPEC (2010). Because of this view, OPEC did not associate itself with estimates of subsidies based on the price-gap methodology in IEA, OPEC, OECD, and World Bank (2010). The author encountered this misunderstanding in Venezuela in the early 1980 s. He was assured that there was little or no subsidy to the consumption of petroleum products, because prices covered the cost of production, which was well below the export price.

There is a sense in which the OPEC view displays economic logic - although not for "countries that are well-endowed with energy" that are not members of OPEC. From the point of view of any of the 12 members of OPEC (Algeria, Angola, Ecuador, Iran, Iraq, Kuwait, Libya, Nigeria, Qatar, Saudi Arabia, United Arab Emirates, and Venezuela), the existence of production quotas means that, aside from the benefit of conserving oil reserves for future years (and cheating, which will not be considered further), the world price of petroleum does not really represent an opportunity cost. Except for the fact that reserves have future value, there would be no reason for these countries not to make petroleum products available to their populations at prices below world prices, as long as they covered costs of production. The specter of exhaustion of reserves would, of course, change the calculation. If, for example, a country thought it had only two year's worth of reserves left, it would rationally assign a value to depletion in the current year equal to the discounted value of the price that could be realized one year hence. The enormous reserves that some OPEC members hold makes it understandable that they might not assign a high opportunity cost to domestic consumption.

${ }^{36}$ In advanced countries sharing of resource wealth commonly takes the form of lower non-resource taxes or higher spending, rather than consumption subsidies. Alaska provides each resident an annual cash "dividend." In Texas the permanent school fund receives royalties from minerals (especially oil and gas) produced on land that it owns. Some resource-rich nations have established sovereign wealth funds and some US states and Canadian provinces have "heritage trust funds" IEA, OECD, and World Bank (2010), p. 44, provides a brief description of some of these. It notes, p. 43, "The main objectives of oil funds are to shield the domestic economy from the volatility of world prices, to foster investment in branches other than natural-resources exploitation, and to share income equitably
} 


\section{Some Difficulties of Implementing the Price-gap Methodology}

Implementing the price-gap methodology can be challenging. Only a sampling of the most important challenges can be described here. ${ }^{37}$ First, it may not be possible to determine reference prices for some fuels accurately for all countries. ${ }^{38}$ Although global prices are readily available for some petroleum products, such as gasoline and diesel fuel, prices for natural gas and coal are not uniform and transparent. Moreover, most coal is sold under long-term contracts, whereas the prices that are reported are those associated with spot sales or sales under short-term contracts. Even in the case of oil, adjustments must be made for the type of fuel.

It is especially difficult to establish reference prices for energy sources that are not traded. Natural gas may be "stranded" without access to world markets, due to the lack of pipelines and facilities for liquifying gas. ${ }^{39}$ In such a case, the reference price may appear to be quite low - essentially production cost, plus the cost of domestic transportation, distribution, insurance, and VAT. In fact, the reference price should depend on the (perhaps unknown) opportunity cost of leaving the gas in the ground for future exploitation.

Since electricity, the primary outlet for coal, is generally not traded internationally (at least among the countries that subsidize its consumption), international prices cannot be used to establish a basic cost. Long-run marginal cost (LRMC) is thus used as a proxy. The volatility of commodity prices and the dysfunction of credit markets may make estimates of LRMC unreliable. (Raw materials are an important element of construction costs, and financing is crucial for long-lived investments in generating capacity and transmission facilities.) Moreover, there may be substantial differences in regional costs within a country.

Second, world prices must be adjusted to take account of the cost of moving fuel to export markets or from import points to points of consumption, which depends on the type of fuel and the geographical characteristics of countries. Accurate information on transportation margins may not exist for some countries or may vary in quality. It is common to employ a single estimate (or a few estimates) of unit costs of transportation for each type of fuel in calculating reference prices, regardless of country-specific factors, such as terrain, distance traveled, quality of transportation infrastructure, and economies in bulk shipments. ${ }^{40}$

across generations." Lack of time and expertise precludes a thorough discussion of this topic. See, however, Davis, Ossowski, Daniel, and Barrett (2003).

${ }^{37}$ On the difficulties of implementing the price-gap methodology and the implications of these difficulties, see Koplow (2009).

${ }^{38}$ See Koplow (2009), pp. 6-7. Kaplow notes that global prices for energy may be distorted by non-competitive elements such as OPEC and by fuel subsidies in other countries. The implication seems to be that the basic assumption underlying the calculation of subsidies, that reference prices represent the social cost of energy, may not be valid. Seen from the viewpoint of any single non-OPEC country, this point seems irrelevant. The social cost of energy to that country is the world price; whether or not those prices are competitively determined seems to be beside the point. If one were interested in estimating the magnitude of subsidies offered by a member of OPEC that can exert significant market power or of those offered by all OPEC countries considered together it would be relevant to consider non-competitive forces. See the discussion in the text at note 57.

${ }^{39}$ In this case there is no difference between a consumption and a production subsidy.

${ }^{40}$ See Koplow (2009), pp.7-8. Noting that domestic transportation and distribution costs in developing countries are, on average, "remarkably similar" to those in developed countries, Gupta, Clements, Fletcher, and Inchauste (2003), p. 387, use costs from G-7 countries. At only about $2 \%$ of total costs, differences in international transportation costs 
Third, there is some disagreement on the proper treatment of taxes. ${ }^{41}$ The World Bank does not include taxes in end-use prices. By comparison, the IEA includes value-added taxes in calculating reference prices, the argument being that they are a normal cost of doing business. Some other taxes are really user chargers collected to pay for amelioration or remediation of damages related to energy use. ${ }^{42}$ As such, they should also be included in costs, rather than being netted from the end-user price.

\section{The Sensitivity of Fuel Subsidies to Movements in International Fuel Prices}

Pricing of fossil fuels can be characterized in one of three ways: as sporadic and ad hoc price setting; as automatic price adjustments, perhaps based on formulas; and as liberalized pricing that reflects market forces. Subsidies are generally greatest under the first regime ${ }^{43}$ and essentially non-existent under the last, except when generally applicable taxes are not applied to fuel and/or electricity.

If fuel prices are held constant or modified only infrequently, higher international fuel prices will imply greater subsidies, and thus larger economic distortions, more serious shortages, increased smuggling, more negative budgetary impacts, and greater deterioration of the country's foreign exchange position. ${ }^{44}$ Formula-based automatic price increases would mitigate this effect, if only with a delay. But automatic adjustments have often been suspended in the face of large and rapid increases in international prices, to mitigate the deleterious effect on household incomes. Liberalized pricing helps assure that subsidies do not occur and that they do not grow when international prices rise. Even in that case, fuel prices may be frozen or fuel taxes may be lowered temporarily to prevent the full pass-through of increases in international fuel prices. ${ }^{45}$ Subsidy reform may thus be a casualty of increases in international fuel prices. ${ }^{46}$

could not matter much. These authors note, however (p. 387), that shipping costs may be higher than assumed in the former Soviet Union, because of ice-blocked ports and pipeline constraints.

${ }^{41}$ See Koplow (2009), p. 8.

${ }^{42}$ Consistent with the discussion of note 32 above, it can be argued that the external cost of $\mathrm{CO} 2$ emissions should be included in the calculation of costs used to measure subsidies. On the other hand, it can be asserted that costs external to the country are not relevant in calculating subsidies; see note 13 above. Generally, no adjustment is made for external costs.

${ }^{43}$ Baig, Mati, Coady, and Ntamatungiro (2007), p. 9, note “... in several cases, ad hoc adjustments translated into prolonged price freezes ..."

${ }^{44}$ Effects on emissions of $\mathrm{CO} 2$ are hard to tease out. In theory, greater subsidies induce more emissions. But this effect is properly measured relative to a level of emissions that would be lower in the no-subsidy counterfactual, due to the higher international price of fuel.

${ }^{45} \mathrm{UN}$-Energy (2005), p. 15 gives such a policy qualified support:

In countries that impose high taxes on imported petroleum fuels, lowering these taxes when oil prices are high and volatile is a way to protect the poor. Helping and protecting poor households requires governments to balance short term support in terms of subsidies with the longer term need to let market forces influence the choice of fuels and energy practices. ...

${ }^{46}$ Arze del Granado, Coady, and Gillingham (2010), p. 16, note that both Ghana and Indonesia abandoned efforts to reform fuel subsidies in response to increases in fuel prices and (in Appendix table 5) cite evidence that the passthough of international fuel price increases deteriorated when fuel prices rose between 2004 and mid 2008. See also Baig, Mati, Coady, and Ntamatungiro (2007), pp. 8-9, and IEA (2012a), pp. 71-72. 
Subsidies to the consumption of fossil fuel were 35\% greater in 2010 than in 2009 (\$409 billion vs. $\$ 300$ billion) and 28\% higher than that in 2011 (\$523 billion). Increases in subsidies did not necessarily reflect a decision to increase subsidy rates. Indeed, many countries were reducing or phasing out subsidies. Rather, it commonly reflected the fact that subsidized prices did not rise in step with the international price of fuels. ${ }^{47}$ Table 1 shows that the percentage changes in subsidies and in international oil prices in each year from 2007 to 2011. Except for the relatively small change in subsidies from 2010 to 2011 , the percentage changes in subsidies exceeded the percentage changes in oil prices,.as might be expected a priori. ${ }^{48}$

\footnotetext{
${ }^{47 ،}$ "The increase in the cost of fossil-fuel subsidies between 2010 and 2011 primarily reflects higher international energy prices and rising consumption of subsidised fuels. The estimated subsidy bill would have been even higher had it not been for policy interventions to reform subsidy programmes in a number of countries ... " IEA (2012a), pp. 69-70. Citing IEA (2010), APEC (2012), p. 15, notes, "The considerable variations of figures between years are mainly due to fluctuations in world prices, ... but also the result of changes in domestic pricing policies, variations in exchange rates with the U.S. dollar and shifts in demand." For an analysis of how subsidies and taxes on petroleum in various types of countries changed as oil prices changed between 20003 and 2008, see Coady et al. (2010), pp. 6-10.

${ }^{48} \mathrm{~A}$ simple example is instructive. Assume that in year 1 the international price of oil is 100 and the domestic price of fuel is 60 , so the subsidy is 40 or $40 \%$. Assume now that the price of oil rises by $40 \%$ or 40 , but the domestic price of fuel is unchanged at 60 , so the subsidy increases to 80 , or by $100 \%$. The ratio of the percentage increase in the subsidy to the percentage increase in the price of oil is $100 \% / 40 \%=2.5$.

The above example assumes implicitly that the quantify of fuel consumed is the same in both years. If $120 \%$ as much fuel is consumed in the second year as in the first, increasing from a normalized value of 1.0 to 1.2 , the subsidy in the second year 2 is 96 , or $120 \%$ more than in the first year, and the ratio of percentage increases is $120 \% / 40 \%=3.0$. If, on the other hand, consumption falls by $20 \%$, the ratio would be 2.0 .

More generally, let $\mathrm{O}$ be the international price of oil in the first year and let $\mathrm{F}$ be the domestic price of fuel in the first year. If consumption is constant at a normalized value of 1.0, both the subsidy per unit of consumption and the amount of the subsidy are $(\mathrm{O}-\mathrm{F})$ and the subsidy rate is $(\mathrm{O}-\mathrm{F}) / \mathrm{O}$. If the price of oil increases by $\mathrm{I}$, the price of oil in the second year is $\mathrm{O}+\mathrm{I}$ and the fractional change in the price of oil is $\mathrm{I} / \mathrm{O}$. If the domestic price of fuel is unchanged at $\mathrm{F}$, the per unit subsidy in the second year becomes $\mathrm{O}+\mathrm{I}-\mathrm{F}$ and the fractional increase in the subsidy is $\mathrm{I} /(\mathrm{O}-\mathrm{F})$. The ratio of the fractional change in subsidies to the fractional change in the price of oil is thus $[\mathrm{I} /(\mathrm{O}-\mathrm{F})] /[\mathrm{I} / \mathrm{O}]=\mathrm{O} /(\mathrm{O}-\mathrm{F})$ which is the inverse of the subsidy rate in the first year. It is, of course, possible to allow for changes in consumption.
} 
Table 1: Estimated subsidies to the consumption of fossil fuel, 2007-2011 ( $\$$ billions); percentage changes in subsidies, compared to percentage changes in oil import prices

\begin{tabular}{|l|c|c|c|c|c|}
\hline & 2007 & 2008 & 2009 & 2010 & 2011 \\
\hline Oil & 186 & 285 & 122 & 193 & 285 \\
\hline Gas & 74 & 135 & 85 & 91 & 104 \\
\hline Coal & 0 & 4 & 5 & 3 & 3 \\
\hline Electricity & 81 & 130 & 88 & 122 & 131 \\
\hline Total & 342 & 554 & 300 & 409 & 523 \\
\hline$\%$ change from prior year & n.a. & +62.0 & -55.8 & +35.3 & +27.9 \\
\hline IEA average price of oil imports $(\$ /$ barrel) & 69.33 & 97.19 & 60.4 & 78.13 & 107.61 \\
\hline$\%$ change from prior year & n.a. & +40.2 & -37.9 & +29.4 & +37.7 \\
\hline $\begin{array}{l}\% \text { change in subsidies as fraction of \% } \\
\text { change in price of oil imports }\end{array}$ & n.a. & 154.2 & 147.2 & 120.0 & 74.0 \\
\hline
\end{tabular}

Sources: IEA (2011) p. 508 ; IEA (2012a), pp. 69-70; "Crude oil import prices and index," available online at: http://stats.oecd.org/BrandedView.aspx?oecd_bv_id=eneprice-data-en\&doi=eneprice-data-en. Pre-2011 figures do not reflect revisions.

A survey of 51 developing and emerging market countries reveals that pass-through of increases in international prices for gasoline during the 2003-06 period was far higher in oilimporting countries (an average of 109\%) than in oil-exporting countries (an average of 46\%). This is perhaps to be expected, since the latter group of countries may feel less pressure to pass price increases through to consumers, since the budgetary impact of higher fuel prices is positive. But the oil-exporting countries in the sample were not the fabulously rich countries of the Middle East, which were not included in the sample. (Azerbaijan, Indonesia, Nigeria, and Russia were included; Venezuela was not.) The countries with the lowest pass-through ratios were Lebanon, Bangladesh, Argentina, Egypt and Azerbaijan. In these countries prices increased very little or actually declined from 2003 to 2006, even though international fuel prices rose. ${ }^{49}$ Pass-through ratios were smaller for kerosene and diesel fuel - an average of $83 \%$, compared to $96 \%$ for gasoline. This "probably reflects their relative importance in the consumption basket of poor households and a desire to limit increases in transport and industrial costs."

The sensitivity of fuel subsidies to movements in international fuel prices implies that the information on fuel subsidies in 2011 presented in the next section should be seen as indicating only orders of magnitude, based on a snapshot for that year. For earlier or later years in which fuel prices are higher or lower, subsidies - as a fraction of reference prices, in dollar terms, as a

\footnotetext{
${ }^{49}$ Baig, Mati, Coady, and Ntamatungiro (2007), pp. 4-5. The survey was conducted among IMF economists working in 51 countries, but results are not reported for all these countries for all types of fuel.

${ }^{50}$ Baig, Mati, Coady, and Ntamatungiro (2007), pp. 5-6.
} 
percent of GDP, and relative to budget revenues, expenditures, and deficits - may be higher or lower. Of course, the last-mentioned percentages are also sensitive to the magnitudes of these budgetary figures, which are affected by macroeconomic conditions, as well as policy decisions..

\section{Quantification of Fuel Subsidies and Their Effects}

This section presents IEA global estimates of subsidies for the consumption of fossil fuels in 2011, estimates of some of the most important effects of eliminating subsidies, and reports country-specific estimates of subsidies for the 37 countries for which the IEA has complete data. ${ }^{51}$ See Table 2 . While some of these are fabulously oil-rich countries, which together provide the lion's share of fuel subsidies, others, including some that export oil, are poor. In Table 3 these subsidy data are combined with fiscal data from the IMF to calculate the budgetary impacts of subsidies offered by the 37 countries.

\footnotetext{
${ }^{51}$ There are probably many more countries that subsidize the consumption of fossil fuel, for example, in sub-Saharan Africa. del Granado, Coady, and Gillingham (2010) list 15 countries that subsidize fuel consumption that are not included in Table 2. Of these, 9 are in Sub-Saharan Africa, 3 are in South America, 1 is in Asia, and 2 are in the Middle East. Since most of these countries are very poor, their fuel subsidies are not likely to be large in monetary terms, either in the aggregate or on a per-person basis. Nor are global environmental effects likely to be significant. (In at least some countries, they are likely swamped by those resulting from inefficient combustion of biomass.) But subsidy rates, local economic effects, and perhaps subsidies as a percentage of both GDP and budget variables may be fairly large.
} 
Reforming Subsidies for Fossil Fuel Consumption

Table 2: Level and composition of subsidies to the consumption of fossil fuel; subsidy rates, 2011

\begin{tabular}{|c|c|c|c|c|c|c|c|c|}
\hline \multirow[t]{2}{*}{ Country } & \multicolumn{5}{|c|}{ Dollar amount of subsidies ( $\$$ billion) } & \multirow[b]{2}{*}{$\begin{array}{l}\text { Average } \\
\text { subsidy rate } \\
\text { (\%) } \\
\text { (f) } \\
\end{array}$} & \multirow{2}{*}{$\begin{array}{l}\text { Subsidies } \\
\text { per person } \\
(\$ / \text { person }) \\
(\mathrm{g})\end{array}$} & \multirow[b]{2}{*}{$\begin{array}{c}\text { Subsidies as a } \\
\text { share of GDP } \\
(\%) \\
\text { (h) }\end{array}$} \\
\hline & $\begin{array}{l}\text { Oil } \\
\text { (a) }\end{array}$ & $\begin{array}{c}\text { Gas } \\
\text { (b) }\end{array}$ & \begin{tabular}{|l|} 
Coal \\
(c)
\end{tabular} & $\begin{array}{c}\text { Electricity } \\
\text { (d) }\end{array}$ & $\begin{array}{r}\text { Total } \\
\text { (e) }\end{array}$ & & & \\
\hline Iran & 41.39 & 23.4 & 0 & 17.4 & 82.19 & 70.0 & 1102.2 & 17.0 \\
\hline Saudi Arabia* & 46.12 & 0 & 0 & 14.82 & 60.94 & 79.5 & 2291.2 & 10.6 \\
\hline Russia* & 0 & 21.87 & 0 & 18.28 & 40.15 & 18.4 & 283.4 & 2.2 \\
\hline India & 30.86 & 3.03 & 0 & 5.81 & 39.70 & 18.6 & 33.4 & 2.4 \\
\hline China & 18.45 & 0 & 1.39 & 11.21 & 31.05 & 4 & 23.1 & 0.4 \\
\hline Venezuela* & 21.97 & 1.89 & 0 & 3.22 & 27.08 & 80.5 & 920.0 & 8.6 \\
\hline Egypt* & 15.27 & 3.78 & 0 & 5.42 & 24.47 & 54.2 & 296.5 & 10.4 \\
\hline Iraq* & 20.35 & 0.29 & 0 & 1.59 & 22.23 & 64.3 & 772.5 & 19.3 \\
\hline UAE* & 3.93 & 11.52 & 0 & 6.37 & 21.82 & 69.1 & 4172. & 6.1 \\
\hline Indonesia* & 15.72 & 0 & 00 & 5.56 & 21.28 & 23.2 & 90.7 & 2.5 \\
\hline Mexico* & 15.9 & 0 & 0 & 0 & 15.90 & 16.6 & 144.4 & 1.4 \\
\hline Algeria* & 11.26 & 0 & 0 & 2.13 & 13.39 & 60.7 & 372.2 & 7.0 \\
\hline Uzbekistan & 1.06 & 9.09 & 0 & 2.59 & 12.74 & 60 & 448.5 & 28.1 \\
\hline Kuwait* & 4.34 & 2.08 & 0 & 4.68 & 11.10 & 87.8 & 3729.3 & 6.3 \\
\hline Pakistan & 2.79 & 5.54 & 0 & 2.75 & 11.08 & 35.4 & 83.0 & 5.3 \\
\hline Thailand & 3.29 & 0.48 & 0.85 & 5.67 & 10.29 & 20 & 150.0 & 3.0 \\
\hline Argentina $^{*}$ & 1.7 & 3.76 & 0 & 4.57 & 10.03 & 25.4 & 246.1 & 2.2 \\
\hline Ukraine & 0 & 6.68 & 0 & 2.66 & 9.34 & 25.5 & 205.4 & 5.7 \\
\hline Malaysia $^{*}$ & 5.35 & 0.89 & 0 & 0.94 & 7.18 & 18.4 & 253.4 & 2.6 \\
\hline Qatar ${ }^{*}$ & 2.03 & 1.86 & 0 & 2.09 & 5.98 & 78.6 & 3622.0 & 3.4 \\
\hline Kazakhstan $^{*}$ & 3.19 & 0.33 & 0.58 & 1.75 & 5.85 & 32.6 & 359.3 & 3.3 \\
\hline Turkmenistan & 0.83 & 4.36 & 0 & 0.65 & 5.84 & 81 & 1115.4 & 22.7 \\
\hline Bangladesh & 0.87 & 1.89 & 0 & 3.00 & 5.76 & 44 & 34.7 & 5.1 \\
\hline Ecuador $^{*}$ & 5.44 & 0 & 0 & 0.12 & 5.56 & 53.7 & 378.6 & 8.4 \\
\hline Nigeria $^{*}$ & 3.62 & 0 & 0 & 0.73 & 4.35 & 33.2 & 26.7 & 1.8 \\
\hline Vietnam $^{*}$ & 1.02 & 0.16 & 0.02 & 2.92 & 4.12 & 15.5 & 46.7 & 3.4 \\
\hline Libya $^{*}$ & 2.26 & 0.21 & 0 & 0.66 & 3.13 & 76.9 & 487.3 & 8.5 \\
\hline Azerbaijan & 0.65 & 0.83 & 0 & 0.47 & 1.95 & 35.8 & 215.9 & 3.1 \\
\hline Taiwan & 0.45 & 0 & 0.15 & 1.02 & 1.62 & 3.9 & 70.3 & 0.3 \\
\hline Philippines & 1.46 & 0 & 0 & 0 & 1.46 & 4.3 & 15.3 & 0.7 \\
\hline South Africa & 0 & 0 & 0 & 1.38 & 1.38 & 4.6 & 27.6 & 0.3 \\
\hline Angola & 1.06 & 0 & 0 & 0.28 & 1.34 & 26.8 & 68.7 & 1.3 \\
\hline Sri Lanka & 0.82 & 0 & 0 & 0.28 & 1.10 & 24.1 & 52.9 & 1.9 \\
\hline Colombia ${ }^{*}$ & 0.65 & 0 & 0 & 0 & 0.65 & 4.8 & 13.9 & 0.2 \\
\hline El Salvador & 0.26 & 0.35 & 0 & 0 & 0.60 & 29.7 & 97.1 & 2.7 \\
\hline Brunei & 0.31 & 0 & 0 & 0.16 & 0.47 & 36.5 & 1158.60 & 3.0 \\
\hline Korea & 0 & 0 & 0.19 & 0 & 0.19 & 0.3 & 3.8 & 0.0 \\
\hline
\end{tabular}

Fossil-fuel consumption subsidies designated as "electricity" represent subsidies that result from the under-pricing of only electricity generated by fossil fuels, i.e. factoring out the component of electricity price subsidies attributable to nuclear and renewable energy.

*Net oil exporter

Source: IEA (2012b). 
International Center for Public Policy Working Paper Series

Table 3: Subsidies, revenues, expenditures, and budget deficits as a percent of GDP; subsidies as a percent of revenues, expenditures, and budget deficits, 2011

\begin{tabular}{|c|c|c|c|c|c|c|c|}
\hline Country & $\begin{array}{l}\text { Subsidies as a } \\
\text { share of GDP } \\
(\%) \\
\text { (a) }\end{array}$ & $\begin{array}{c}\text { Revenues as a } \\
\text { share of GDP } \\
\text { (\%) } \\
\text { (b) }\end{array}$ & $\begin{array}{l}\text { Expenditures as a } \\
\text { share of GDP } \\
(\%) \\
\text { (c) }\end{array}$ & $\begin{array}{l}\text { Budget surplus } \\
\text { as a share of } \\
\text { GDP } \\
\text { (\%) } \\
\text { (d) }\end{array}$ & $\begin{array}{l}\text { Subsidies as a } \\
\text { share of revenues } \\
(\%) \\
\text { (e) }\end{array}$ & $\begin{array}{l}\text { Subsidies as a share } \\
\text { of expenditures } \\
\text { (\%) } \\
\text { (f) }\end{array}$ & $\begin{array}{l}\text { Subsidies as a share } \\
\text { of budget surplus } \\
(\%) \\
(\mathrm{g})\end{array}$ \\
\hline Iran & 17.0 & 24.8 & 25.0 & -0.2 & 68.5 & 68.1 & -10000 \\
\hline Saudi Arabia* & 10.6 & 53.3 & 39.3 & 14.0 & 19.9 & 27.0 & 76.0 \\
\hline Russia* & 2.2 & 38.4 & 36.8 & 1.6 & 5.7 & 6.0 & 141.0 \\
\hline India & 2.4 & 18.5 & 27.5 & -9.0 & 13.0 & 8.7 & -26.7 \\
\hline China & 0.4 & 22.7 & 23.9 & -1.2 & 1.8 & 1.7 & -32.45 \\
\hline Venezuela* & 8.6 & 35.2 & 40.7 & -5.4 & 24.4 & 21.1 & -159.3 \\
\hline Egypt* & 10.4 & 22.0 & 32.0 & -9.9 & 47.3 & 32.5 & -105.1 \\
\hline Iraq* & 19.3 & 78.1 & 70.5 & 7.6 & 24.7 & 27.4 & 253.9 \\
\hline UAE* & 6.1 & 35.0 & 23.9 & 11.2 & 17.4 & 25.5 & 54.7 \\
\hline Indonesia* & 2.5 & 17.8 & 18.6 & -0.8 & 14.0 & 13.5 & -328.9 \\
\hline Mexico* & 1.4 & 22.1 & 25.5 & -3.4 & 6.3 & 5.5 & -41.3 \\
\hline Algeria* & 7.0 & 39.6 & 39.8 & -0.2 & 17.7 & 17.6 & -3684.2 \\
\hline Uzbekistan & 28.1 & 40.2 & 31.2 & 9.0 & 69.9 & 90.1 & 312.2 \\
\hline Kuwait* & 6.3 & 67.6 & 38.5 & 29.1 & 9.3 & 16.4 & 21.6 \\
\hline Pakistan & 5.3 & 12.8 & 19.2 & -6.4 & 41.4 & 27.6 & -83.3 \\
\hline Thailand & 3.0 & 22.7 & 24.2 & -1.6 & 13.2 & 12.4 & -187.5 \\
\hline Argentina $^{*}$ & 2.2 & 37.3 & 40.3 & -3.0 & 5.9 & 5.5 & -72.4 \\
\hline Ukraine & 5.7 & 42.4 & 45.1 & -2.7 & 13.4 & 12.6 & -211.1 \\
\hline Malaysia $^{*}$ & 2.6 & 21.9 & 28.8 & -6.9 & 11.9 & 9.0 & -37.8 \\
\hline Qatar ${ }^{*}$ & 3.4 & 38.6 & 26.5 & 12.1 & 8.8 & 12.8 & 28.2 \\
\hline Kazakhstan" & 3.3 & 27.8 & 21.9 & 5.9 & 11.9 & 15.1 & 55.9 \\
\hline Turkmenistan & 22.7 & 18.9 & 15.2 & 5.6 & 120.1 & 149.3 & 405.4 \\
\hline Bangladesh & 5.1 & 11.9 & 16.0 & -4.1 & 42.9 & 31.8 & -124.4 \\
\hline Ecuador $^{*}$ & 8.4 & 40.9 & 41.9 & -1.1 & 20.6 & 20.0 & -800.0 \\
\hline Nigeria $^{*}$ & 1.8 & 29.5 & 29.2 & 0.2 & 6.1 & 6.2 & 900.0 \\
\hline Vietnam $^{*}$ & 3.4 & 27.7 & 30.9 & -3.2 & 12.3 & 11.0 & -106.3 \\
\hline Libya $^{*}$ & 8.5 & 38.5 & 63.0 & -24.5 & 22.1 & 13.5 & -34.7 \\
\hline Azerbaijan & 3.1 & 45.5 & 34.2 & 11.3 & 6.8 & 9.1 & 27.4 \\
\hline Taiwan & 0.3 & 18.8 & 22.5 & -3.6 & 1.6 & 1.3 & -8.3 \\
\hline
\end{tabular}


Table 3: Subsidies, revenues, expenditures, and budget deficits as a percent of GDP; subsidies as a percent of revenues, expenditures, and budget deficits, 2011 (cont.)

\begin{tabular}{|c|c|c|c|c|c|c|c|}
\hline Country & $\begin{array}{l}\text { Subsidies as } \\
\text { a share of } \\
\text { GDP } \\
(\%) \\
\text { (a) }\end{array}$ & $\begin{array}{l}\text { Revenues as } \\
\text { a share of } \\
\text { GDP } \\
\text { (\%) } \\
\text { (b) }\end{array}$ & $\begin{array}{l}\text { Expenditures as } \\
\text { a share of GDP } \\
(\%) \\
\text { (c) }\end{array}$ & $\begin{array}{l}\text { Budget } \\
\text { surplus as a } \\
\text { share of GDP } \\
(\%) \\
\text { (d) }\end{array}$ & $\begin{array}{l}\text { Subsidies as a } \\
\text { share of } \\
\text { revenues } \\
(\%) \\
\text { (e) }\end{array}$ & $\begin{array}{l}\text { Subsidies as a } \\
\text { share of } \\
\text { expenditures } \\
(\%) \\
\text { (f) }\end{array}$ & $\begin{array}{l}\text { Subsidies as a } \\
\text { share of budget } \\
\text { surplus } \\
(\%) \\
(\mathrm{g})\end{array}$ \\
\hline Philippines & 0,7 & 17.3 & 18.1 & -0.8 & $4 / 0$ & 3.9 & -87.5 \\
\hline South Africa & 0.3 & 27.5 & 32.1 & -4.6 & 1.1 & 0.9 & -6.6 \\
\hline Angola & 1.3 & 48.8 & 38.5 & 10.2 & 2.7 & 3.4 & 12.7 \\
\hline Sri Lanka & 1.9 & 14.5 & 21.4 & -6.9 & 13.1 & 8.9 & -27.5 \\
\hline Colombia $^{*}$ & 0.2 & 26.9 & 28.7 & -1.8 & 0.7 & 0.7 & -11.1 \\
\hline El Salvador & 2.7 & & & & & & \\
\hline Brunei & 3.0 & 62.2 & 32.0 & 30.2 & 4.8 & 9.4 & 9.9 \\
\hline Korea & & 23.4 & 21.6 & 1.8 & 0.0 & 0.0 & 0.0 \\
\hline
\end{tabular}

"Net oil exporter

Source: Column (a): IEA (2012b); government spending (inclusive of grants), revenues, and deficits as a percentage of GDP: IMF (2012). Figures for Angola, Argentina, Colombia, Iran, Iraq, Korea, Kuwait, and Venezuela are IMF staff estimates. 


\section{A. The Magnitude of Fuel Consumption Subsidies}

The IEA estimates that subsidies to the consumption of fossil fuels in those 37 countries amounted to $\$ 523$ billion in 2011 , nearly $25 \%$ more than the figure for 2010 . Subsidies to the consumption of oil products ( $\$ 285$ billion) represented $54 \%$ of the total. Electricity generated by burning fossil fuels ( $\$ 131$ billion) accounted for just over $25 \%$ of the total and natural gas (\$104 billion) for $20 \%$. Coal, with less than 1 percent of the total ( $\$ 3.2$ billion), may appear to be strangely absent, but its primary contribution is included in the figure for electricity, as is the contribution of oil and gas for that purpose. (The estimates reported here do not identify the composition of fuel inputs for subsidized generation of electricity.) China, Thailand, and Kazakhstan are the only countries in which subsidies to coal consumption, per se, amounted to as much as $\$ 500$ million. ${ }^{52}$ The weighted average fuel subsidy rate was $24 \%{ }^{53}$

\section{B. The Global Benefits of Removing Fuel Subsidies}

The IEA has produced illustrative estimates of the energy savings, reductions in CO2 emissions, and increases in global GDP that would result from phasing out fossil fuel subsidies between 2012 and 2020. Because subsidy rates fluctuate from year-to-year, the initial subsidy rate employed in making these estimates is the average for the three year period, 2008-2010. The baseline assumes that subsidy rates remain unchanged at that level. ${ }^{54}$

Not all the benefits of eliminating subsidies reported here are likely to be realized, because it is unlikely that all subsidies will be eliminated. Indeed, leaving political opposition aside, it may be appropriate, for reasons discussed in the next two sections, to retain some subsides either for distributional reasons or to encourage fuel switching. On the other hand, because, subsidies are likely to be greater than reported above, the benefits of eliminating them would also be greater. Since consumption subsidies are heavily concentrated in oil-rich countries, especially in the Middle East, results are heavily dependent on whether and to what extent subsidy reforms occur in those countries.

The cost of fuel subsidies is projected to reach $\$ 660$ (in 2010 dollars) or $0.7 \%$ of global GDP by 2020 , if no further reductions occur. Some of these costs would be explicit, exerting pressure on budgets, and some implicit, initially affecting the financial condition of state oil companies. A review of 6 studies revealed an increase in global GDP resulting from the elimination of fuel subsidies ranging from $0.1 \%$ in total by 2010 to $0.7 \%$ per year to $2050 .{ }^{55}$

The IEA estimates that if fossil fuel subsidies were eliminated, global energy demand would be lower by $3.9 \%$ in 2020 and by $4.8 \%$ in 2035 . Energy savings increase over time because consumption

\footnotetext{
${ }^{52}$ UNDP and WHO (2009). Coal is used for cooking and heating by as much as $4 \%$ of the population in only a few countries: Chad (4.9\%; rural: $1.1 \%)$, China (28.9\%; rural: $29.8 \%$; urban $27.7 \%)$, Guinea (19.2\%; rural: $3.1 \%$; urban: 59.6\%), Laos (21.2; rural:10.8\%; urban: 44\%), Mongolia (19.4\%; rural:3.8; urban: 31.3\%), Mozambique (12.6\%; rural:0.9\%; urban: $40.8 \%$ ), Paraguay (13.8\%; rural: $7.9 \%$; urban: $17.5 \%$ ), and Vietnam (5.2\%; rural: $4.5 \%$ ). The rural figure is also high in Brazil (5.4\%). The figure for coal use in rural Mongolia is so low because an astonishing $49.5 \%$ of the population relies on dung.

${ }_{53}^{53}$ IEA (2012b), pp. 69-70..

${ }^{54}$ Except as noted, this discussion is based on that in IEA (2011a), p. 520-22, which is more extensive than that in IEA (2012a).. Attempts are made to model a shift to a more energy-efficient world in IEA (2012a).

${ }^{55}$ Ellis (2010). The studies cited employ the price-gap methodology. See also OECD (2009), pp. 101-109.
} 
becomes more price-elastic with the passage of time. Percentage reductions vary from country to country, depending on the country-specific price elasticity of demand and the country's subsidy rate. ${ }^{56}$

The IEA does not attempt to translate these estimates into excess burdens avoided. Four economists at the IMF have estimated for 1999 the deadweight loss resulting from fuel consumption subsidies offered by oil-producing countries. ${ }^{57}$ These estimates alternatively ignore environmental externalities or assume that they amount to $\$ 0.10$ per liter of fuel. They also take account of the possibility that some of the largest oil exporters exert monopoly power over petroleum prices or that OPEC does so. The authors find that, except in the case of monopoly power by OPEC, the optimal price would entail a tax in all countries, instead of a subsidy, and that the implied tax rate is substantially higher if account is taken of environmental externalities than if they are ignored. Only if OPEC exerts monopoly power and environmental externalities are ignored is a member of OPEC justified in subsidizing fuel consumption. The argument is that, from a point of view of members of OPEC (and contrary to the view underlying the price-gap methodology), domestic prices should not be as high as export prices that reflect market power. Even in that case the implied subsidy rate is only one-half the actual rate.

Emissions of $\mathrm{CO} 2$ would fall with the consumption of energy. The IEA estimates that $\mathrm{CO} 2$ emissions would fall by $4.7 \%$ in 2020 and by $5.8 \%$ in 2035 . Environmental benefits that were not modeled include reductions in sulphur dioxide, nitrous oxides, and particulates.

\section{Country-Specific Estimates of Subsidies}

The 37 countries for which the IEA provides data on fuel consumption subsidies are all either developing countries, countries in transition, middle-income countries, or - by far the most important petroleum-producing countries. ${ }^{58}$ (Of course, some countries fit in more than one of these categories.) The dollar magnitude of Iran's subsidies ( $\$ 82$ billion) was by far the largest, despite reforms introduced in 2010, ${ }^{59}$ followed by those of Saudi Arabia (\$61 billion) and Russia (\$40 billion). Together these three oil-producing countries accounted for roughly $35 \%$ of global subsidies to consumption of fossil fuel. India and China, each with more than $\$ 30$ billion in subsidies, together accounted for roughly another 10\% of the total. Pakistan ( $\$ 11$ billion) and Bangladesh ( $\$ 6$ billion) are other particularly poor countries lacking significant oil production that are found high on the list of countries subsidizing fuel consumption, ordered by the monetary magnitude of subsidies. Incredibly, Pakistan is in $15^{\text {th }}$ place, just behind Kuwait, and Bangladesh is in $23^{\text {rd }}$ place, two slots ahead of Nigeria.

Dollar amounts are not the most relevant way to characterize fuel subsidies for many purposes. As noted, the weighted average subsidy rate across all 40 countries was $24 \%$. Average subsidy rates were at least $75 \%$ in five net oil-exporting countries, Kuwait (87.8\%), Venezuela (80.5\%), Saudi Arabia (79.5\%), Qatar (78.6\%), and Libya (76.0\%), and in Turkmenistan $(81 \%$, primarily for the

\footnotetext{
${ }^{56}$ IEA (2011), p. 521.

${ }^{57}$ Gupta, Clements, Fletcher, and Inchauste (2003), pp. 389-96. These estimates assume an optimal uniform consumption tax of 10 percent and a price elasticity of demand of -0.5 .

${ }^{58}$ Except for the data for El Salvador, which the IEA provided the author, the figures reported in this subsection are from IEA (2012b). To obtain data for a particular country from the map, it is necessary to click on the country.

${ }^{59}$ The importance of these reforms is indicated by the near constancy of the dollar amount of Iran's subsidies, which rose by only \$1 billion from 2010 to 2011, compared to an increase of $25 \%$ for all countries - or about one-third if Iran is excluded..
} 
consumption of gas), were between $60 \%$ and $70 \%$ in three more, Iran (70\%) the United Arab Emirates - UAE (69.1\%), and Algeria (60.7\%\%), and exceeded 50\% in three others, Uzbekistan (57.1\%, also primarily for gas consumption), Egypt (54.2\%), and Ecuador (53.7\%). What is more astonishing and disturbing, given the relatively low rates of access to modern fuels in these two countries $(9 \%$ in Bangladesh and 32\% in Pakistan), the subsidy rate was $44 \%$ in Bangladesh (where 52\% of subsidies went to electricity and 33\% went to natural gas) and 35.4\% in Pakistan (50\% to natural gas and $25 \%$ each to oil and electricity).

Per capita subsidies to the consumption of fossil fuels - a measure that illustrates clearly just how wasteful subsidies are - exceeded $\$ 2,000$ per year in 4 countries, all of them oil-rich Middle Eastern countries (UAE: \$4,172; Kuwait: \$3,729; Qatar: \$2,622; and Saudi Arabia: \$2,291). Per capita subsidies also exceeded $\$ 750$ in Turkmenistan $(\$ 1,115)$, Brunei $(1,159)$, Iran $(\$ 1,102)$, Venezuela (\$920), and Iraq (\$773).

The economic cost of subsidies is perhaps easiest to understand if expressed as a percentage of GDP. ${ }^{60}$ In this regard, Uzbekistan is the clear winner - or loser - with $28.1 \%$. Turkmenistan $(22.7 \%)$, Iraq (19.3\%), Iran (17\%), are the only other countries in which subsidies exceed $15 \%$ of GDP. This figure exceeds 10\% in Saudi Arabia (10.6\%), and Egypt (10.4\%), and 5\% in Venezuela (8.6\%), Libya (8.5\%), Ecuador (8.4\%), Algeria (7\%), Kuwait (6.3\%), the UAE (6.1\%), Ukraine (5.7\%), Pakistan (5.3\%) and Bangladesh (5.1\%). Although Egypt and Ecuador both export oil, they like Ukraine, Pakistan, and Bangladesh do not belong on a list dominated by oil-rich countries. In particular, Bangladesh and Pakistan can ill afford to devote this much of their GDP on fuel subsidies, even if per capita subsidies are small in dollar terms (\$35 in Bangladesh and \$83 in Pakistan). The level of subsidies in Bangladesh is particularly worrisome, since only $9 \%$ of the population have access to modern fuels. ${ }^{61}$ Although providing large dollar amounts of subsidies, India (2.4\%) and China (0.4\%) devote relatively small amounts of GDP to fuel subsidies.

\section{Budgetary Impacts of Fuel Subsidies}

Table 3 compares fossil fuel subsidies to government spending, revenue, and budget deficits for $2011 .^{62}$ Subsidies as a share of budgetary spending were extremely high in 3 countries whose governments might be described as benighted: $149.3 \%$ in Turkmenistan, $90.1 \%$ in Uzbekistan, and $68.1 \%$ in Iran. Other countries where this ratio exceeded 20\% were Bangladesh (31.8\%), Egypt (32.6\%), Saudi Arabia (27.0\%), Iraq (27.4\%), UAE (25.6\%), Pakistan (27.6\%), Venezuela (21.1\%), and Ecuador (20.0\%), While the shares were more modest in other countries, they exceeded $10 \%$ of expenditures in nine of them. Subsidies exceeded 2/3 of budget revenues in Turkmenistan (120.1\%), Uzbekistan (69.9\%), and Iran (68.1\%) and exceeded 40\% of revenues in Egypt (47.3\%), Bangladesh (42.9\%), and Pakistan (41.1\%).

\footnotetext{
${ }^{60}$ This is, however, not necessarily the best way to express economic costs. Deadweight loss is proportionate to the square of the subsidy rate.

${ }^{61}$ UNDP and WHO (2009), p. 71. GSI (2012), p. 22, notes that Bangladesh has agreed to liberalize fuel prices, with automatic formula-based adjustments of fuel prices, as part of an agreement with the IMF.

${ }^{62}$ Data on government revenues, spending, and deficits as a percentage of GDP are from IMF (2012). Figures for Angola, Argentina, Colombia, Iran, Iraq, Korea, Kuwait, and Venezuela are IMF staff estimates. The table reports surpluses, rather than deficits, which appear in the table as negative numbers.
} 
A comparison of subsidies and budget deficits makes sense only if the latter are large enough to matter. Subsidies were greater than budget deficits that exceeded $4 \%$ of GDP in Ukraine $(12.6 \%$ vs. $5.7 \%$ ), Venezuela ( $8.6 \%$ vs. $5.5 \%$ ), Bangladesh (5.1\% vs. $4.1 \%$ ), and Egypt (10.4\% vs. 9.9\%). Other countries combining subsidies of at least $2 \%$ of GDP and budget deficits of at least $4 \%$ of GDP were Pakistan (5.3\% vs. $6.4 \%$ ) Malaysia (2.6 vs. $6.9 \%$ ), and Lybia (8.5\% vs. $24.5 \%$ ). These figures suggest that deficits in these countries could be reduced substantially, if not eliminated, by reforming fuel subsidies, even if some of the savings from subsidy reform were devoted to income maintenance for the poor. Where deficit finance is not a problem, reduction of fuel subsidies could provide badly needed public funds.

The names of certain countries that are not major oil-exporters (e.g., Bangladesh, Ecuador, Egypt, Pakistan, and Ukraine) appear repeatedly in the above description of the magnitude of subsidies. It is reasonable to ask whether the populations of some of the countries with high ratios of subsidies to spending and revenues, if fully aware of the cost of subsidies, the distribution of benefits, and alternatives, might not prefer spending on social services, rather than fuel subsidies ${ }^{63}$ Information on the distribution of benefits of fuel subsidies across income classes and on alternative ways of providing income support, described in the next two sections, suggests that the provision of subsidies for the consumption of fossil fuels is misguided. Clearly, it is not the best way to deal with poverty, if that is the objective.

It must be emphasized that the calculations presented in the previous paragraphs are intended only to illustrate that fuel subsidies may represent low-hanging revenue fruit. But, as noted earlier, the IEA has warned that the estimates produced using the price-gap methodology should be considered a lower limit on the size of subsidies. Considerably more detailed analysis would be required to determine, for each country, the nature and size of fuel subsidies and how much of the cost of fuel subsidies could realistically be shifted to deficit reduction or expansion of public spending. That would, of course, depend on the necessity, feasibility, method, and cost of compensating low-income households for the loss of purchasing power represented by fuel subsidies, as well as the possibility of mobilizing for public purpose revenues needed to replace subsidies that are only implicit.

\section{The Distributional Effects of Fuel Subsidies}

Subsidies to the consumption of fossil fuel are commonly introduced and defended ostensibly as a means of reducing the burden of fuel prices on the real incomes of the poor. In fact, a variety of studies show that fuel subsidies are quite ineffective in achieving this result. Because the studies cover different collections of countries, rely on different kinds of data, and employ different methodologies, it is difficult to integrate them.

Based on a survey of 11 of the countries that subsidized consumption of fossil fuels in 2010 , the IEA estimates that only $8 \%$ of the $\$ 409$ billion spent on fuel subsidies benefitted the poorest $20 \%$ of the population. ${ }^{64}$ The percentage of subsidies benefitting this group varied from only $2 \%$ in South Africa to

\footnotetext{
${ }^{63}$ Increasing awareness of the distribution of benefits of subsidies is a standard and important component of descriptions of strategies for implementing subsidy reform. See the sources cited in note 9.

${ }^{64}$ This discussion and that of the next paragraph draws heavily on IEA (2011), pp. 518-21. A chart showing the percentage of benefits reaching the poorest quintile in each country appears on page 519. The countries, listed in decreasing order of the percentage of subsidies benefitting the poorest quintile of the population, were Pakistan, China, Vietnam, Thailand,
} 
$11 \%$ in Pakistan. If fuel subsidies were truly disproportionately benefitting the poor, this figure would exceed $20 \%{ }^{65}$ Often poor households lack access to subsidized natural gas and electricity and cannot even dream of owning a vehicle that runs on subsidized motor fuel.

Subsidies to kerosene consumption are the most effective in reaching the poor, despite the incentive to smuggle this fuel to other countries or divert it to uses not intended for subsidization. Nearly $15 \%$ of kerosene subsidies benefitted the lowest quintile of populations. By comparison, subsidies to liquified petroleum gas (LPG), diesel fuel, and gasoline were the least effective in reaching the poor; only 5 to $6 \%$ of their benefits went to the poorest quintile. In the case of LPG, the heavy initial cost of equipment and the practice of selling gas in large quantities (compared to sales of kerosene) creates a barrier to its use by the poorest households. With shares of 9 and $10 \%$, respectively, benefitting the poorest quintile, electricity and natural gas fall in the middle of the range. These results demonstrate that fossil fuel subsidies are an inefficient means of helping the poor and suggest that there are probably more cost-effective and less distortionary ways of achieving the same distributional objective, namely cash grants and social welfare programs.

Subsidies to the consumption of fossil fuel affect real incomes primarily through two channels. ${ }^{66}$ The direct impact occurs when households pay higher prices for fuel and electricity used for heating, lighting, cooking, and private transportation. Its distributional effects depend on the distribution of subsidies across types of fuel and the importance of expenditures on each type of subsidized fuel purchased for these purposes at various points in the income distribution. The indirect impact is transmitted through higher prices paid for goods and services, including public transportation. Its distributional effects depends on the fuel-intensity of various products (particularly utilization of diesel fuel and electricity as inputs to transportation and other sectors), as well as consumption patterns and the distribution of subsidies among fuel types. Since estimates of distributional effects generally do not allow for substitution away from fuel and other products that become more expensive, they should be interpreted as either short-run impacts or upper limits on long-run impacts.

That fuel consumption subsidies are an ineffective way to benefit the poor is hardly surprising. In many of the poorest countries, including several that subsidize fuel consumption, a large share of the population does not even have access to modern fuels ${ }^{67}$ Instead, they utilize wood, charcoal, straw, agricultural residue, dung, or coal for heating and cooking. The UNDP and WHO (2009), p. 14, lists 22 countries in which no more than $5 \%$ of the population has access to modern fuels. The access rate is

Indonesia, Angola, Bangladesh, India, Philippines, Sri Lanka, and South Africa. The IEA selected these 11 countries "on the basis of data availability for those that have low levels of modern energy access, and have an aggregate population of 3.4 billion." IEA (2011), p. 519. Bangladesh is the only one of these 11 countries that is among the 42 mentioned in the discussion that follows of results reported in UNDP and WHO (2009).

${ }^{65}$ The accuracy of this statement depends on how proportionality is defined. Because of inequality in the distribution of income, far less than $20 \%$ of the benefits of a fuel subsidy that increased all incomes proportionately would accrue to the poorest $20 \%$ of the population.

${ }^{66}$ Like most of the literature, this discussion focuses on the effects on real incomes that are transmitted through the effects fuel subsidies have on fuel prices. There may also be effects on employment and incomes in the fuel sector and in sectors in which fuel is an important input, such as transportation and agriculture. GSI (2012) emphasizes the link through agriculture in Bangladesh.

${ }^{67}$ For this purpose, access to modern fuels refers to use of these fuels for cooking, which generally implies use for heating as well. Access to electricity, which means an electrical connection, is included in access to modern fuels only if electricity is used for cooking. See UNDP and WHO (2009), p. 6. Access rates for electricity are much higher than those for modern fuel. They are at least $25 \%$ in all but 6 countries of the world's poorest nations, all of which are small island nations, and they are at least 75\% in many; UNDP and WHO ()2009, p. 12. 
less than $10 \%$ in 29 countries and below $25 \%$ in 42 . Almost all of these countries are located in SubSaharan Africa or Asia. Households without access to modern fuels are almost certainly the poorest in each country.

In Bangladesh, where the subsidy rate was $44 \%$ in 2011 , less than $10 \%$ of the population relies on modern fuel; the other $90 \%$ are thus unlikely to benefit from fuel subsidies, except indirectly. In Pakistan, both the subsidy rate (35\%) and the percentage of the population lacking access to modern fuels $(68 \%)$ were lower, but it is again unlikely that fuel subsidies have much impact in reducing the burden of acquiring fuel at the bottom of the income distribution. Even in Nigeria, an important oil exporter that has a subsidy rate of $33 \%$, less than $3 / 4$ of the population relies on modern fuel. ${ }^{68}$

The direct benefits of subsidies to fuels that are used by only a small percentage of a country's population accrue primarily to the elites; they are inevitably highly regressive ${ }^{69}$ It seems highly unlikely that the indirect effects of fuel subsidies would be weighted so heavily in favor of the poor that the overall effects of fuel subsidies would not be regressive.

Arze del Granado, Coady, and Gillingham (2010) review studies of the distributional implications of subsidy reform in 20 countries, 9 from Africa, 4 from Latin America, 5 from Asia, and 2 from the Middle East, by examining the effects of a US $\$ 0.25$ per liter increase in the price of fuel in each of the countries. The result, on average, is a $5.9 \%$ decline in real income, with a low of $3.8 \%$ in the Latin American countries and a high of $9.6 \%$ in the Middle East. Significantly, more than half of the impact is indirect. Data for 12 of the countries ( 8 of them in Africa) reveal that, although transportation represents only $3.3 \%$ of household expenditures, it accounts for $10 \%$ of the indirect impact fuel subsidies have on real income, due to the high energy intensity of the sector. Food accounts for just under $40 \%$ and non-food for just over $50 \% .^{70}$

The composition of direct impacts differs quite markedly across countries. In Ghana and Indonesia the posited increase in the price of kerosene would cause real income to fall by $5.0 \%$ and $4.1 \%$, respectively. In only 3 other countries is the decline as much as $1.0 \%$. By comparison, reflecting the lack of access to automobiles in the poorest countries, increasing gasoline prices reduces real income by more than $0.7 \%$ only in Lebanon, where the decline is $1.9 \%$. Because many households lack access to certain types of fuel, figures on direct impacts may substantially understate the impact of a price increase on households that do have access. Thus, for example, if the access rate is only $10 \%$, a $0.4 \%$ overall impact on real income would translate into a $4.0 \%$ impact on households with access. ${ }^{71}$

\footnotetext{
${ }^{68}$ Information on the percentage of populations that rely on modern fuels are from UNDP and WHO ()2009, pp. 71-77; see also Ekouevi and Tuntivate (2011), p. 2, which indicates that the share of the population relying on traditional fuels exceeds $70 \%$ in five oil-exporting countries in Sub-Saharan Africa, the highest share being Chad's 91.2\%. These authors note (p. 5) that in 2008 the IEA estimated that, over the period 2006-30, 10 oil- and gas-exporting countries in Sub-Saharan Africa could provide minimal energy services, such as electricity and LPG cylinders and stoves, to households at a cost of only $0.4 \%$ of revenues from oil and gas exports.

${ }^{69}$ This result is confirmed in Bangladesh, where only $8.8 \%$ of the population has access to modern fuel (UNDP and WHO, 2009 , p. 71) and the top two income classes enjoy almost $80 \%$ of the direct benefits of subsidies to natural gas and LPG and almost $90 \%$ of the direct benefits of subsidies to petrol and diesel; see GSI (2012), p. 16. Unfortunately, there is no indication of the percentage of households that have each level of income or of the percentage of income accruing to them. Moreover, this analysis does not include the indirect benefits of fuel subsidies. GSI (2012), p. 15. Much more of these would, of course, accrue to lower income groups.

${ }^{70}$ Arze del Granado, Coady, and Gillingham (2010), p. 10.

${ }^{71}$ Arze del Granado, Coady, and Gillingham (2010), pp. 8-10.
} 
Fuel subsidies were found to be neutral in their impact on the distribution of income across quintiles in these countries. This means that, as a way to support the income of the poor, fuel subsidies are badly targeted. But distributional impacts varied considerably by type of fuel. Subsidies to the consumption of kerosene provided relatively more benefit to the poor, as a percentage of income, while gasoline and electricity subsidies worsened the distribution of income. Estimates of the distribution of subsidy benefits tells the same story. The top quintile receives roughly 6 times as much in benefits as the bottom quintile $(42.0 \%$ vs. $7.3 \%$ ). In the case of gasoline and electricity this ratio was much higher, 20 and 14 times as much, respectively. In the case of kerosene, each quintile received roughly 20 percent of the benefits of subsidies. ${ }^{72}$

Electricity subsidies provide relatively more benefits, the greater is household income. This phenomenon may reflect lack of connections for the poor more than differences in consumption patterns for those that are connected. In El Salvador, for example, for those with positive consumption, electricity subsidies represent about the same percentage of income in all quintiles but the top one, where it is lower. But almost one-third of households in the bottom quintile lack connections, compared to an average of about $6 \%$ in the other 4 quintiles. While lifeline tariffs have the potential to minimize electricity costs for households that are connected to the grid, they provide no benefits to those that are not. Extending access to the poor may thus be one of the most effective ways to provide fuel subsidies to the poor. ${ }^{73}$

There is often an urban bias in the availability of subsidized fuel. Thus the UNEP (2008), p. 15, observes regarding LPG subsidies in India:

LPG subsidies mainly benefit higher-income households. ... An estimated 76 per cent of this subsidy is allocated in urban areas, which contain only one quarter of the population. Of this urban subsidy, over half is enjoyed by approximately one quarter of households. This means that almost 40 per cent of the LPG subsidy benefits a mere 7 per cent of the population. Moreover, the subsidy represents less than 5 per cent of expenditure for this segment of the population. This is a far lower share than what Indians living below the poverty line spend on kerosene. ${ }^{74}$

On implication is, of course, that subsidizing use of kerosene is a far more effective anti-poverty policy than subsidizing use of LPG.

\section{Protecting the Poor When Fuel Subsidies Are Reformed}

In the absence of fuel subsidies, the cost of fuel consumption can impose an onerous burden on the poor. ${ }^{75}$ But, as a means of providing income support for the poor, fuel subsidies are generally poorly targeted and highly ineffective. They simply do not provide much "bang for the buck."

\footnotetext{
${ }^{72}$ Arze del Granado, Coady, and Gillingham (2010), pp. 10-12. The appendix to that paper contains breakdowns by regions.

${ }^{73}$ Arze del Granado, Coady, and Gillingham (2010), p. 12.

${ }^{74}$ Subsidies to electrification may, in principal, benefit rural households, but if they result in deficits for the state-owned electrical company, it may be the poor who endure power outages.

${ }^{75}$ On the topic of this section, see the references in IEA, OECD, and World Bank (2010), pp. 38-41.
} 
According to Arze del Granado, Coady, and Gillingham (2010, pp. 11-12), it would cost \$14 dollars in subsidies, on average, to transfer $\$ 1$ to households in the lowest quintile of the income distribution. Subsidies for kerosene are better targeted, as this ratio is only about $\$ 5$. But even this is an inefficient way to help the poor. The cost-effectiveness of kerosene subsidies is limited by the risk of smuggling and substitution of subsidized kerosene for unsubsidized diesel fuel. Even if fuel subsidies are relatively well targeted to relieve burdens on the poor, they distort resource allocation and put a strain on public sector budgets. Thus, as Baig, Mati, Coady, and Ntamatungiro (2007), p. 14, note, "As most fuel subsidies accrue to higher income households, it should be possible to eliminate or substantially reduce subsidies, use some of the budgetary savings to finance better targeted-programs to compensate the poorest households, and still have funds left over." ${ }^{, 76}$ This section discusses how to protect the poor when fuel subsidies are reformed.

Subsidies to the consumption of fossil fuel do not only affect real income, through what economists call income effects. They also have substitution effects; by altering the relative prices of fuels and other goods and services, they distort consumer choices, encouraging over-consumption (and perhaps waste) of fuel and the emission of greenhouse gases. Moreover, unless targeted carefully, they also benefit the non-poor and distort their choices. This line of reasoning suggests that, subject to the possibility (discussed in the next section) that fuel subsidies can have a desirable substitution effect, by inducing switching from biomass and coal to modern fuel, policies that have only income effects and that benefit primarily the poor should be utilized to protect the real income of the poor when fuel subsidies are reformed.

The case for mitigating the negative impacts of subsidy reform varies from country to country. It is useful to distinguish, as in the previous section, between direct and indirect effects of subsidy reform. Only households with access to modern fuels would suffer directly from subsidy reform, though many more may suffer indirectly. In the 22 countries in which no more than $5 \%$ of the population has access to modern fuels (or the 29 in which less than $10 \%$ of the population has access to modern fuel), the case for offsetting the direct impact of subsidy reform would seem weak, as few of those who would be harmed directly by subsidy reform are likely to be the poorest members of society. ${ }^{77}$ In such countries it is probably more sensible to concentrate on trying to offset the indirect effects of reform, which would not be so heavily concentrated at the top of the income distribution. The case for compensation for direct impacts of reform would be stronger in countries where large fractions of the population rely on subsidized fuel. Even in those cases, it may be difficult to compensate the poor for the direct impact of subsidy reform.

The feasibility of mitigating negative impacts that subsidy reform would have on the poor also varies from country to country. The choice of techniques to be used to mitigate burdens on the poor as fuel subsidies are phased out will depend in part on the institutions and administrative capacity of the country and its government. Where social safety nets exist, they can be expanded or improved, by using information on socioeconomic and demographic characteristics to target relief to particularly vulnerable

\footnotetext{
${ }^{76}$ Arze del Granado, Coady, and Gillingham (2010), p. 13.

${ }^{77}$ Readily available data do not reveal whether these countries subsidize consumption of fossil fuel, except in the case of Bangladesh, where the average subsidy rate is $44 \%$ and subsidies amount to $5.1 \%$ of GDP, although only $9 \%$ of the population have access to modern fuel. In five of the countries examined in Arze del Granado, Coady, and Gillingham (2010 ), which are presumed to subsidize fossil fuel consumption, less than $5 \%$ of the population has access to modern fuel, and in three more countries (including Bangladesh), less than 10\% do.
} 
parts of the population (e.g., the elderly, children, the unemployed, and those living in areas of high poverty) ${ }^{78}$ It may be possible to exploit local knowledge (for example, that of teachers or community leaders) to target cash payments. ${ }^{79}$ Better targeting makes it possible to achieve the same or better distributional results, while avoiding distortions and spending less. ${ }^{80}$ But any such techniques are vulnerable to abuse or outright corruption.

Where social safety nets do not exist or are inadequate, it may be necessary to use more indirect ways of helping the poor, such as subsidized school meals, reduced fees for education and health care, subsidies to urban mass transport, life-line tariffs, and, where feasible, cash transfers to vulnerable groups. Public spending that is especially beneficial to the poor can also be expanded, such as health and education expenditures, expansion of rural roads, and electrification. ${ }^{81}$

Arze del Granado, Coady, and Gillingham (2010), p, 15, describe the experience of five countries (Gabon, Ghana, Mozambique, Indonesia, and Jordan) in reforming fuel subsidies. Among the actions taken to relieve the burden on the poor in one or more of these countries were the following: cash payments to the poor, assistance to single mothers, increased funding of microcredit programs targeting disadvantaged rural women, lifeline tariffs for water and electricity, waiver of school fees, free textbooks, investment in rural health services, electrification, and drinking water supply, increased access to LPG, and an increase in the minimum wage.

There is a strong case for eliminating most subsidies to consumption of fossil fuels. There would be allocational, environmental, budgetary, and foreign exchange benefits. But there may a case in some countries for temporarily retaining well-targeted fuel subsidies (e.g., temporarily retaining subsidies to kerosene, while phasing out other fuel subsidies), recognizing the limitations of such a policy (budgetary cost, limited distributional impact, economic distortions, the risk of smuggling and diversion to replace diesel fuel) - and the risk that subsidies retained "temporarily" will become permanent. Among the reasons are the difficulty of quickly implementing well-designed alternatives (cash grants and spending programs), the advantages of reducing reliance on biomass and coal, and the benefits of electrification. As UNEP says:

In practice, there may be a good case for retaining an element of subsidy to improve access to modern energy sources for the poor - especially where social welfare infrastructure for distributing income support to the poor does not exist. This argument is particularly strong for electricity because of its key role in economic and social development, in alleviating poverty and reducing indoor pollution. Therefore, subsidies

\footnotetext{
${ }^{78}$ It may make sense to means-test cash transfers, but being overly ambitious would, in effect, introduce many of the complications that plague ill-advised attempts to implement universal income taxation in developing countries. It would require an attempt to determine the income of households that are generally exempt from income tax, for administrative reasons, as well as on equity grounds. For a useful discussion of targeting income maintenance programs, including a "Checklist of Economic Considerations in Price-Subsidy Reform," albeit not in the context of reform of fuel subsidies, see Gupta et al. (2000). There is also a useful discussion of political considerations in the design of subsidy reform.

${ }^{79}$ For a review of experience with social safety nets in Indonesia, Mexico, and Brazil, see IEA, OECD, and World Bank (2010), pp. 40-42.

${ }^{80}$ IEA, OPEC, OECD, and World Bank (2010), p. 38, notes that "some of the better known and effective programs spend around $0.5 \%$ of GDP." This compares favorably with the figures for subsidies as a percentage of GDP for most countries reported in Table 2,

${ }^{81}$ Arze del Granado, Coady, and Gillingham (2010), p. 13.
} 
are likely to remain a major part of pro-poor energy policies in developing countries for some time. The challenge is to make sure that they do not lead to excessive levels of energy consumption and environmental damage. UNEP (2008), p. 21

That there may be a case for well-targeted fuel subsidies in some cases does not mean that most subsidies should not be eliminated. All to often, and for too long, fuel subsidies have been promoted, enacted, and retained on the grounds that they are needed to protect the poor from high energy prices, when in fact they benefit primarily the non-poor.

\section{Incentives to Switch from Traditional Fuels}

As noted in the Introduction, the use of traditional fuels (biomass and coal) for cooking and heating is associated with serious problems - problems not associated with the use of modern fuels (kerosene, gas and electricity) - and is unsustainable in many countries. Cooking and heating with biomass or coal in poorly ventilated quarters causes respiratory diseases (mainly pneumonia, chronic respirator disease, and, in the case of coal, lung cancer), especially among women and young children, and carries a risk of burns and uncontrolled fires. The need to gather wood and carry it home, which may consume several hours per day in some cases, takes women and children from more productive activities, participation in the remunerated economic activities in the former case and education in the latter. ${ }^{82}$ The use of cow dung for fuel reduces the organic content of soil and thus soil fertility, and deforestation leads to soil erosion and eliminates an important carbon sink. ${ }^{83}$ Many of those who use traditional fuels do not have access to improved cook stoves, some of which reduce the need for fuel used in cooking by as much as 30 percent. In 26 countries, almost all of them in Sub-Saharan Africa, no more than $10 \%$ of those using solid fuel have access to stoves that embody improved technology. ${ }^{84}$

There is also a distributional element to this problem, as access to modern fuels is least common in the least developed countries, is less prevalent in rural areas than in urban areas, and is especially uncommon among the poorest members of society. Indeed, since income is generally higher in urban than in rural areas and access to modern fuels is substantially lower in rural areas, fuel subsidies are almost inevitably regressive, even leaving aside the distribution of subsidy benefits among those who do utilize the subsidized fuels.

\footnotetext{
${ }^{82}$ For a useful survey of issues related to the combustion of biomass and coal, see von Schirnding et al. (2002); see also Ekouevi and Tuntivate (2011), pp. 5-9 .

${ }^{83}$ von Schirnding et al (2002), p. 22, note, however, that deforestation and erosion resulting from the burning of wood may be overstated, because most wood used for cooking and household heating is collected, rather than cut. Moreover, Ekouevi and Tuntivate (2011), p. 9, note, "It is now widely accepted that the clearing of land for arable and pastoral agriculture is the main cause of deforestation rather than the use of wood for energy, as was believed in the past." The last authors note (p. ix) that there are, however, exceptions, such as areas surrounding growing urban areas in some Sub-Saharan African countries and Haiti.

${ }^{84}$ WHO and UNDP (2009), p. 21. In Bangladesh, one of the two Asian countries on this list, only $2 \%$ of those using traditional fuels have access to improved cooking stoves.
} 
It may appear that there is a case for subsidizing the consumption of fossil fuels other than coal, in order to induce fuel switching. ${ }^{85}$ Thus the UNEP says, "Where they result in switching from traditional fuels and in improved access to electricity, those subsidies can bring considerable benefits to poor communities. These include less indoor pollution and a reduction in the time women and children spend gathering fuel and, therefore, more time for productive activities like farming, and education." ${ }^{86}$ A case study for Uganda that focuses on these issues advocates government intervention to encourage transition to modern fuels. ${ }^{87}$

According to this reasoning, it may not always be enough to provide cash grants to the poor or provide public services of special significance to the them when fuel subsidies are eliminated. Elimination of fuel subsidies does create a level playing field between traditional and modern fuels. But, compared to the distorted situation with fuel subsidies, such a neutral policy means that there is a substitution effect that encourages the use of biomass or coal instead of fossil fuels. ${ }^{88}$ Thus, a "Citizen's Guide to Energy Subsidies in Bangladesh" warns, "Fuel subsidy reform could lead to an increase in biomass consumption. This should be an important consideration for government when designing reform policies and accompanying support measures for low-income groups." ${ }^{" 89}$ This reasoning suggests that in extremely poor countries there may be a case for retaining (or providing) well-targeted subsidies to the use of fossil fuels other than coal. ${ }^{90}$

On the other hand, there is evidence that fossil fuel subsidies are not effective in inducing the poor to shift from biomass to modern fuels, except perhaps in urban areas, where access to, and use of,

${ }^{85}$ A given household does not only use only one type of fuel, moving up the "energy ladder" as its income improves or it is induced to switch fuels because of shifts in relative prices. Heltberg (2004), p. 870-71, observes:

The 'energy ladder model' underlies much of research, analysis, and policy formulation in the area of household energy. The energy ladder model conceptualizes fuel switching in three distinct phases. The first phase is characterized by universal reliance on biomass. In the second phase of fuel switching households are hypothesized to move to "transition" fuels such as kerosene, coal, and charcoal in response to higher incomes, urbanization, and biomass scarcity. The third and final phase of fuel switching is characterized by households switching to LPG, natural gas, or electricity for cooking. Growing incomes in conjunction with relative fuel prices are seen as determining factors for the speed with which households fuel switch by moving up the energy ladder. The major empirical achievement of the energy ladder model is the ability to capture the strong income dependence of fuel choices. ...

Yet the ladder image is perhaps unfortunate because it appears to imply that a move up to a new fuel is simultaneously a move away from fuels used hitherto. ... In fact, uptake of a new cooking fuel far from always displaces traditional fuels. Many households in developing countries routinely use multiple cooking fuels.

${ }^{86}$ UNEP (2008), p. 14.

${ }^{87}$ Mwaura, Okoboi, and Ahaibwe (no date).

${ }^{88}$ The IEA (2011), p. 497, observes, "While advanced cookstoves can help cut wood fuel use substantially, the economic arguments alone may not be compelling for many households, especially if wood fuel is considered "free" and the time of the persons collecting it - typically women and girls - is not sufficiently valued." The health benefits of fuel switching, which accrue mainly to women and children, may not be recognized or valued highly.

${ }^{89}$ GSI (2012), p. 19. Citizen's Guides have also been prepared for India, Indonesia, and Nigeria.

${ }^{90}$ Access to fuel (e.g., connections to the electrical grid and the ready availability of LPG in containers small enough that the poor can afford them) may be as important as price in determining switching to modern fuel. Thus policy should sometimes be targeted to providing more widespread access. Also important is the availability of micro-credit that allows poor households to make the capital investments needed to use clean fuel. 
modern fuels is much more common and access to biomass is not as easy. ${ }^{91}$ Heltberg $(2004$, p. 885) states:

There are not many policy options for promotion of fuel switching. Price subsidies for modern fuels have historically been used in the name of promoting fuel switching - but price subsidies are often undesirable because of their high fiscal costs, poor targeting (especially in the case of LPG), and leakage (in the case of kerosene). Kerosene subsidies would in many cases have the most pro-poor distribution, but kerosene sold for fuel is inevitably re-directed to automotive uses on a large scale. ... Subsidized kerosene is therefore little effective as a tool for fuel switching, despite the fact that among all the modern cooking fuels kerosene probably competes the closest with firewood.

The UNEP document quoted above goes on to say:

In reality, however, these subsidies often benefit mainly the energy companies, equipment suppliers and the better-off households, especially in the towns and cities. In some cases, they may not even reach the poor at all. As a result, many energy-subsidy programmes intended to boost poor households' purchasing power or rural communities' access to modern energy through lower prices can, paradoxically, leave the poor worse off, since the costs are shared by the entire population including the poor. ${ }^{92}$

The choice of fuel to use for cooking and heating appears to be highly dependent on income level and education, the latter perhaps because of the higher implied opportunity cost of using solid fuel. ${ }^{93}$ About 3 billion people currently rely on traditional fuels and, since income and educational achievement are unlikely to be increased rapidly, an estimated 2.8 billion will do so in $2030 .{ }^{94}$ Thus, "clean energy" efforts have been directed not so much at fuel switching as at improved use of traditional fuels - assuring adequate supplies of fuelwood, improved ventilation, and uptake of clean stoves, which can decrease emissions of GHGs and particulates, health risks, and the amount of time spent in gathering fuel. ${ }^{95}$ Some energy-efficient stoves are more affordable than switching to stoves that burn kerosene or LPG. Even so, subsidies for clean stoves have been disappointing, leading to poor maintenance and abandonment of malfunctioning stoves, as well as high budgetary costs. ${ }^{96}$ Microfinance may facilitate the purchase of an improved stove by the poor. ${ }^{97}$ In some contexts there

\footnotetext{
${ }^{91}$ Heltbert (2004). See also Ekouevi and Tuntivate (2011), pp. 18-19, which emphasizes the role of consumer preferences.

${ }^{92}$ UNEP (2008), p. 14.

${ }^{93}$ Heltberg (2004, p. 885). See also the references in Ekouevi and Tuntivate (2011), p. 8.

${ }^{94}$ IEA (2012a), p. 532. These figures include those cooking with coal.

${ }^{95}$ See Heltberg (2004), p. 886. Ekouevi and Tuntivate (2011), pp. 10-21, reviews the results of World Bank projects focused on household energy access.

${ }^{96}$ Ekouevi and Tuntivate (2011), p. 26.

${ }^{97}$ Ekouevi and Tuntivate (2011), p. 27.
} 
may be a case for subsidizing the development, manufacture, and distribution of improved stoves, rather than subsidizing either the consumption of fossil duels or the purchase of energy-efficient stoves. $^{98}$

\section{Subsidies for Electrification}

The IEA (2011) p. 472, estimates that 1.3 billion people worldwide, or $19 \%$ of the global population, do not have access to electricity. ${ }^{99}$ Of these, more than $95 \%$ live in either Sub-Saharan Africa or the developing countries of Asia, and more than $80 \%$ live in rural areas. Ten countries, four in Asia and six in Africa, together account for almost two-thirds of those without electricity. While Bangladesh is the only one of these four Asian countries with an electrification rate less than $50 \%$, in five of these six African countries, from $77 \%$ to $92 \%$ of the population lacks access to electricity. Whereas the electrification rate is $92 \%$ in urban areas of developing countries, in rural areas it is only $64 \%$. UNEP (2008), p. 27, states the case for subsidizing electrification, especially in rural areas, and perhaps the on-going use of electricity by the poor: ${ }^{100}$

Access to electricity services is essential to alleviate dire poverty and improve living standards. Certain energy services can only be provided effectively by electricity. It is the only practical means of running basic domestic appliances, such as telephones and refrigerators. And it provides the best quality and cheapest form or lighting. ... Good lighting allows people to extend the day, which, in turn, enables them to read or study longer, raising educational levels. Access to electricity also boosts economic productivity, by reducing manual labour. It also leads to better health, by replacing polluting indoor fuels, by improving hygiene with the use of refrigerators and by making it possible to provide modern health services. Electricity, for example, enables doctors and clinics to keep vaccines and medicines refrigerated, so that routine and emergency treatment can be offered locally. ${ }^{101}$

This is a tough nut to crack. If the objective is universal access to electricity, it may be necessary to subsidize electrification, including costs of connecting to the grid, because the poor may lack the ability to pay these costs, either up-front or spread out and included in monthly charges. Improved access to credit could help, if the problem is lack of access, but not if it is low income. ${ }^{102} \mathrm{In}$ any event, it is probably appropriate to subsidize both connection and the use of electricity in schools that serve primarily the poor, because of the public benefits of education.

\footnotetext{
${ }^{98}$ UN-Energy (2005), p. 12.

${ }^{99}$ The data reported here are from IEA (2012a), p. 532-33. For further information on electrification rates in the least developed countries, see WHO and UNDP (2009), pp. 10-12.

${ }^{100}$ See also UNEP (2008), pp. 27-29.

${ }^{101}$ In addition, "In general, subsidies for liquid fuels are particularly difficult to target, given the ease with which such fuels can be sold on the black market. In comparison, the distribution of electricity and piped natural gas is more easily monitored and controlled." IEA, OECD, and World Bank (2010), p. 13.

${ }^{102}$ The "Citizens' Guide to Energy Subsidies in Bangladesh" notes, “[A]chieving this goal [extending electrification to all villages by 2020] depends on tackling rural poverty more effectively, as poor households have little incentive to access electricity when suffering from severe deprivations." (GSI (2012), p. 19
} 
In theory, limiting subsidies for the use of electricity to the poor is most effectively achieved through the use of life-line tariffs - setting a low price for the first tranche of use. By making these low rates available only to those with consumption below a very low level, defined in term of capacity or average consumption, it is possible to avoid applying the low rate to use by other consumers. ${ }^{103}$ But experience has been mixed, in part because of poor design. Until recently, eligibility for the lifeline rate was so generous in Tanzania that many well-off households qualified. ${ }^{104}$ More generally, Komives et al. (2007) find that quantity-based subsidies generally do not perform well in targeting benefits to the poor. They observe (p. 673), "the poor targeting performance of quantity-based subsidies is the combined effect of a coverage gap between the poor and non-poor, the poor performance of quantity consumed as a proxy for income, and the presence of general subsidies and fixed charges. ..." They conclude that geographic targeting is often more effective in limiting benefits to the poor. Data on socioeconomic circumstances of areas can be used to determine where subsidies to electrification are appropriate. ${ }^{105}$

If tariffs are limited to what consumers can pay, investments in electrification may not be financially viable; subsidies are likely to be required. The result may be, in addition to economic distortions and unsustainable budgetary impacts, the inability to serve those who would benefit most from electrification. In India, for example, subsidies were so generous (about $50 \%$ of costs for households and $90 \%$ for farmers) that electricity boards incurred such large losses that they could not meet targets for connecting new villages and rural households. ${ }^{106}$

\section{Concluding Remarks: Reaching Multiple Goals with Subsidy Reform}

The previous discussion suggests the following criteria for judging the efficacy of policies related to subsidy reform: environmental effects (reduced emissions of GHGs, gaseous pollutants, including carcinogens, and particulates); economic effects (reductions in economic distortions, foreign exchange shortages, difficulties of demand management, and energy insecurity); effect on the public budgetary situation; protection of the real incomes of the poor who use fossil fuels directly (including access to public services); and improvement of the situation of the poor who do not now use fossil fuels directly (increased income, including access to public services; improved access to affordable clean fuel and modern stoves). Table 4 is an attempt to indicate the effectiveness of various combinations of policies, as measured against these criteria. A politically important column is omitted from the table: the effects on the real incomes of the non-poor; in all cases these effects are likely to be negative.. These groups are, of course, likely to try to undermine attempts at subsidy reform.

Option 1, subsidy reform, which might involve partial or complete elimination of subsidies to the consumption of fossil fuels, with nothing more, would provide environmental, economic, and budgetary benefits, but would reduce the real incomes of both the poor who use fossil fuel directly and,

\footnotetext{
${ }^{103}$ In theory there would be a "notch" - a discontinuous jump in payment - at the point at which eligibility for the life-line tariff ceases. This is unlikely to be a serious problem if the threshold is set low enough.

${ }^{104}$ UNEP (2008), p. 23.

${ }^{105}$ For a review of experience in this area, see IEA, OECD, and World Bank (2010), pp. 37-40

${ }^{106}$ UNEP (2008), p. 29. By comparison, see the description of favorable experience of Chile in subsidizing rural electrification, p. 28.
} 
through indirect effects on prices, the real incomes of the poor who do not now use fossil fuel directly. It is unlikely to be politically viable.

Options 2 and 3, which combine subsidy reform with either income support or increased public services, would mitigate, and perhaps outweigh, the negative effects on the real incomes of those who consume fossil fuel directly, and might also improve the situation of the poor who do not now consume fossil fuel directly. These distributional effects would, of course, depend on the coverage of income support (especially whether it reached those who do not now consume fossil fuel) and the nature of the increased public services.

Option 4 combines subsidy reform with an effective program to provide clean energy (improved stoves or better ventilation and greater access to biomass) to those who do not now consume fossil fuel, as well as either income support or increased public services. It would provide even greater environmental benefits than the other options, by resulting in less particulate pollution (and, if coal would otherwise be burned inefficiently, fewer carcinogens), and greater economic benefits, by freeing women and children to pursue education and more productive work than gathering firewood. Whether the budgetary situation would improved is unclear.

In short, in many of the countries that subsidize the consumption of fossil fuels it should be possible to kill several birds with one stone - or a few stones. Reforming fuel subsidies would improve resource allocation and have environmental benefits. Details of what is possible beyond that are country specific, but it probably would be possible to use either cash payments or increased public services to protect the real income of the poor. Since the distribution of benefits of subsidies is commonly regressive, in many countries this could probably be achieved while generating budgetary savings. A clean energy program would benefit those not consuming fossil fuels directly.

Table 4: How to Kill More Than on Bird

\begin{tabular}{|l|l|l|l|l|l|}
\hline Instrument & \multicolumn{4}{|l|}{ Objectives } \\
\hline $\begin{array}{l}\text { Subsidy } \\
\text { reform, with: }\end{array}$ & $\begin{array}{l}\text { Environmental } \\
\text { benefits }\end{array}$ & $\begin{array}{l}\text { Economic } \\
\text { benefits }\end{array}$ & $\begin{array}{l}\text { Improved } \\
\text { budgetary } \\
\text { situation }\end{array}$ & $\begin{array}{l}\text { Protecting the real } \\
\text { income of the } \\
\text { poor using fossil } \\
\text { fuel directly }\end{array}$ & $\begin{array}{l}\text { Improvement of the } \\
\text { situation of the } \\
\text { poor not using } \\
\text { fossil fuel directly }\end{array}$ \\
\hline $\begin{array}{l}\text { 1. Nothing } \\
\text { more }\end{array}$ & Yes & Yes & Yes & No & No \\
\hline $\begin{array}{l}\text { 2. Income } \\
\text { support }\end{array}$ & Yes & Yes & $\begin{array}{l}\text { Probably, but } \\
\text { less }\end{array}$ & Yes & $\begin{array}{l}\text { Depends on scope } \\
\text { of support program }\end{array}$ \\
\hline $\begin{array}{l}\text { 3. Increased } \\
\text { public services }\end{array}$ & Yes & Yes & $\begin{array}{l}\text { Probably, but } \\
\text { less }\end{array}$ & Yes & $\begin{array}{l}\text { Depends on nature } \\
\text { of services }\end{array}$ \\
\hline $\begin{array}{l}\text { 4. Option 2 or } \\
\text { 3, with clean } \\
\text { energy } \\
\text { program }\end{array}$ & Yes, greater & Yes, \\
greater & Unclear & $\begin{array}{l}\text { Yes; as in options } \\
\text { and 3 }\end{array}$ & Yes \\
\hline
\end{tabular}


References

APEC Leaders. (2009, November 14-15). Singapore Declaration: Sustaining growth, connecting theregion. 2009 Leader's Declaration. Retrieved October 31, 2011 from:

http://www.apec.org/Meeting-Papers/Leaders-Declarations/2009/2009_aelm.aspx.

Arze del Granado, Javier, David Coady, and Robert Gillingham (2010), "The Unequal Benefits of Fuel Subsidies: A Review of Evidence for Developing Countries:” IMF Working Paper WP/1-/202, September 2010 .

Asia-Pacific Economic Cooperation (APEC), "Reforming Fossil-Fuel Subsidies to Reduce Waste and Limit $\mathrm{CO}_{2}$ Emissions while Protecting the Poor," September 2012).

Baig, Taimur, Amine Mati, David Coady, and Joseph Ntamatungiro, "Domestic Petroleum Product Prices and Subsidies: Recent Developments and Reform Strategies,” IMF Working Paper WP/07/71, March 2007.

Birol, F., Aleagha, A.V. and Ferrouki, R. (1995). "The economic impact of subsidy phase out in oil exporting developing countries: a case study of Algeria, Iran and Nigeria.” Energy Policy. 23(3):209- 215.

Coady, David, Robert Gillingham, Rolando Ossowski, John Piotrowski, Shamsuddin Tareq, and Justin Tyson, "Petroleum Product Subsidies: Costly, Inequitable, and Rising," IMF Staff Position Note SPN/10/05,February 25, 2010.

Davis, Jeffrey, Rolando Ossowski, James A. Daniel, and Steven Barrett, "Stabilization and Saving Funds for Nonrenewable Resources: Experience and Fiscal Policy Implications,” in Jeffrey M. Davis, Rolando J. Ossowski, and Annalisa Fedelino, editors, Fiscal Policy Formulation and Implementation in Oil-Producing Countries (Washington: International Monetary Fund, 2003), pp. 273-315.

Ekouevi, Koffi, and Voravate Tuntivate, "Household Energy Access for Cooking and Heating: Lessons Learned and the Way Forward," World Bank, June 2011.

Espinasa, Ramon, "The Impact of Gasoline Price Subsidies on the Government and the National Oil Company," in Jeffrey M. Davis, Rolando J. Ossowski, and Annalisa Fedelino, editors, Fiscal Policy Formulation and Implementation in Oil-Producing Countries (Washington: International Monetary Fund, 2003), pp. 416-25.

Global Subsidies Initiative (GSI), "Defining Fossil-Fuel Subsidies for the G-20: Which Approach is Best?” 2010, available online at: http://www.iisd.org/gsi/sites/default/files/pb5_defining.pdf. 
Global Subsidies Initiative (GSI), "A Citizens' Guide to Energy Subsidies in Bangladesh,” 2012, available online at: http://www.iisd.org/gsi/sites/default/files/ffs_bangladesh_czguide.pdf.

G-20 Leaders, "Leaders' statement: The Pittsburgh Summit.” The Pittsburgh Summit 2009, 24-25 September. available online at: <http://www.pittsburghsummit.gov/mediacenter/129639.htm>.

Goulder, Lawrence H., "Environmental Taxation and the "Double Dividend:" A Reader's Guide," International Tax and Public Finance, Vol. 2, No. 2 (August 1995, pp. 157-83.

Gupta, Sanjeev, Marijn Verhoeven, Robert Gillingham, Christian Schiller, Ali Mansoor, and Juan Pablo Cordoba, "Equity and Efficiency in the Reform of Price Subsidies: A Guide for Policymakers," International Monetary Fund, December 15, 2000.

Gupta, Sanjeev, Benedict Clements, Kevin Fletcher, and Gabriela Inchauste, "Issues in Domestic Petroleum Pricing in Oil-Producing Countries," in Jeffrey M. Davis, Rolando J. Ossowski, and Annalisa Fedelino, editors, Fiscal Policy Formulation and Implementation in Oil-Producing Countries (Washington: International Monetary Fund, 2003), pp. 383-415,

International Energy Agency (IEA), "World Energy Outlook Insights, Looking at Energy Subsidies: Getting the Prices Right, (1999).

International Energy Agency (IEA), World Energy Outlook 2011 (Paris), 2011.

International Energy Agency (IEA), World Energy Outlook 2012 (Paris), 2012a.

International Energy Agency (IEA), "Fossil-Fuel Consumption Subsidy Rates as a Proportion of the Full Cost Supply, 2011," available at http://www.iea.org/subsidy/index.html, $2012 \mathrm{~b}$.

IEA, OECD, and World Bank, "The Scope of Fossil-fuel Subsidies in 2009 and a Roadmap for Phasing out Fossil-fuel Subsidies," a Joint Report Prepared for the G-20 Summit, Seoul, 11-12 November 2010.

IEA, OPEC, OECD, and World Bank, "Analysis of the Scope of Energy Subsidies and Suggestions for the G-20 Initiative," prepared for submission to the G-20 Summit Meeting Toronto (Canada), 26-27 June 2010, 16 June 2010.

Institute for Energy Research, 2011, "IEA Review Shows Many Developing Countries Subsidize Fossil Fuel Consumption, Creating Artificially Lower Prices," available online at: http://www.instituteforenergyresearch.org/2011/11/23/iea-review-shows-many-developingcountries-subsidize-fossil-fuel-consumption-creating-artificially-lower-prices/.

International Monetary Fund (IMF), “World Economic Outlook Database, October 2012," available online at: http://www.imf.org/external/pubs/ft/weo/2012/02/weodata/weoselgr.aspx 
Koplow, Doug, 2009, "Measuring Energy Subsidies Using the Price-Gap Approach: What Does It Leave Out?" (Winnipeg, Canada: International Institute for Sustainable Development).

Laan, Tara, "Gaining Traction the Importance of Transparency in Accelerating the Reform of Fossilfuel Subsidies," Geneva: Global Subsidies Initiative of the International Institute for Sustainable Development, 2010, available online at: http://www.globalsubsidies.org/files/assets/transparency_ffs.pdf

Mwaura, Francis, Geofrey Okoboi and Gemma Ahaibwe "Understanding Household Choice of Cooking Energy in Addressing Deforestation in Uganda," available at: http://www.trapca.org/working-papers/FrancisMwaura\%28Trapca\%29.pdf.

OECD, Improving the Environment Through Reducing Subsidies, 1998.

OECD, The Economics of Climate Change Mitigation Policies and Opt ions for lobal Act ion beyond 2012. 2009.

Organization of the Petroleum Exporting Countries (OPEC) Secretariat. "Energy Subsidies in the Context of Sustainable Development," (2010), available online at: http://www.iisd.org/gsi/news/energy-subsidies-context-sustainable-development.

Petri, Martin, Günther Taube, and Aleh Tsyvinski, "Energy Quasi-Fiscal Activities in the Countries of the Former Soviet Union," in Jeffrey M. Davis, Rolando J. Ossowski, and AnnalisaFedelino, editors, Fiscal Policy Formulation and Implementation in Oil-Producing Countries (Washington: International Monetary Fund, 2003), pp. 451-82.

UN-Energy, ““'The Energy Challenge for Achieving the Millennium Development Goals,” 2005, available online at: http://www.undp.org/content/undp/en/home/librarypage/environmentenergy/sustainable_energy/the_energy_challengeforachievingthemillenniumdevelopmentgoals. html.

UNEP, "Reforming Energy Subsidies: Opportunities to Contribute to the Climate Change Agenda," (2008).

UNDP and WHO (World Health Organization), "The Energy Access Situation in Developing Countries: A Review Focusing on the Least Developed Countries and Sub-Saharan Africa." (UNDP, New York, 2009).

United States Energy Information Administration, Federal Energy Subsidies: Direct and Indirect Interventions in Energy Markets, 1992, available online at: $\mathrm{ftp}$ //tonto.eia.doe.gov/service/emeu9202.pdf.

von Schirnding, Y., N. Bruce, K. Smith, G. Ballard-Tremer, M. Ezzati, and K. Lvovsky, "Addressing the Impact of Household Energy and Indoor Air Pollution on the Health of the Poor: 

Washington, DC., 2002. 